\title{
Kinematic elements of Antarctic Intermediate Water in the western South Atlantic
}

\author{
Olaf Boebel $^{\mathrm{a}, *}$, Claudia Schmid ${ }^{\mathrm{b}, 1}$, Walter Zenk $^{\mathrm{b}}$ \\ ${ }^{\mathrm{a}}$ Department of Oceanography, University of Cape Town, 7700 Rondebosch, South Africa \\ ${ }^{\mathrm{b}}$ Institut für Meereskunde an der Universität Kiel, Düsternbrooker Weg 20, 24105 Kiel, Germany
}

Received 6 January 1998; received in revised form 2 July 1998

\begin{abstract}
The northward flowing Antarctic Intermediate Water (AAIW) is a major contributor to the large-scale meridional circulation of water masses in the Atlantic. Together with bottom and thermocline water, AAIW replaces North Atlantic Deep Water that penetrates into the South Atlantic from the North. On the northbound propagation of AAIW from its formation area in the south-western region of the Argentine Basin, the AAIW progresses through a complex spreading pattern at the base of the main thermocline. This paper presents trajectories of 75 subsurface floats, seeded at AAIW depth. The floats were acoustically tracked, covering a period from December 1992 to October 1996. Discussions of selected trajectories focus on mesoscale kinematic elements that contribute to the spreading of AAIW. In the equatorial region, intermittent westward and eastward currents were observed, suggesting a seasonal cycle of the AAIW flow direction. At tropical latitudes, just offshore the intermediate western boundary current, the southward advection of an anticyclonic eddy was observed between $5^{\circ} \mathrm{S}$ and $11^{\circ} \mathrm{S}$. Farther offshore, the flow lacks an advective pattern and is governed by eddy diffusion. The westward subtropical gyre return current at about $28^{\circ} \mathrm{S}$ shows considerable stability, with the mean kinetic energy to eddy kinetic energy ratio being around one. Farther south, the eastward deeper South Atlantic Current is dominated by large-scale meanders with particle velocities in excess of $60 \mathrm{~cm} \mathrm{~s}^{-1}$. At the Brazil-Falkland Current Confluence Zone, a cyclonic eddy near $40^{\circ} \mathrm{S} 50^{\circ} \mathrm{W}$ seems to act as injector of freshly mixed AAIW into the subtropical gyre. In general, much of the mixing of the various blends of AAIW is due to the activity of mesoscale eddies, which frequently reoccupy similar positions. (C) 1999 Elsevier Science Ltd. All rights reserved.
\end{abstract}

*Corresponding author. Tel.: 002721650 3280; fax: 002721650 3979; e-mail: oboebel@physci.uct.ac.za.

${ }^{1}$ Now at: NOAA, Atlantic Oceanographic and Meteorological Laboratory, Miami, FL 33149, USA. 


\section{Introduction}

The discussion of the pathway of the low saline and oxygen rich Antarctic Intermediate Water (AAIW) of the South Atlantic at mid-latitudes has long been controversial. Recent large scale hydrographic studies (Reid, 1996; Talley, 1996) depict similar flow fields, but many details regarding the mixing of the AAIW of different flavors (by which we mean AAIW with different hydrographic properties, such as the AAIW in the subtropical gyre and the AAIW in the tropical gyre) remain uncertain. In particular, the mixing processes of newly formed and recirculated AAIW, the exchange of Intermediate Western Boundary Current (IWBC) water with the tropical gyre and the structure of the equatorial flow field managed to hide their secrets since long. Most recently, Larqué et al. (1997) analyzed hydrographic sections from the South Atlantic Ventilation Experiment (SAVE) in the multitracer study. Their concluding schematic flow diagram (their Fig. 5a) depicts the subtropical and tropical gyres as the main circulation elements of the intermediate flow. The equatorial crossing of intermediate water and the alongshelf northward flow of AAIW between $40^{\circ} \mathrm{S}$ and $30^{\circ} \mathrm{S}$ along the western boundary, however, are conceived as elements of uncertainty, as depicted by dashed arrows in their figure.

Addressing the issue of a direct northward flow between $40^{\circ} \mathrm{S}$ and $30^{\circ} \mathrm{S}$, Boebel et al. (1997b) reviewed the distribution and advection of AAIW in the subtropical South Atlantic with special emphasis on the flow around the Rio Grande Rise (Fig. 1a). In agreement with early suggestions by Taft (1963) and Buscaglia (1971) and guided by direct observations from moored current meters and neutrally buoyant floats, the authors favor the basin-wide anticyclonic circulation of AAIW within the deep subtropical gyre over the possible direct northward flow of AAIW along the South American continental slope. The subtropical gyre center appears to be south-east of the Rio Grande Rise, separating the eastward advection of AAIW as deep South Atlantic Current (Stramma and Peterson, 1990) from the westward recirculation flow around $30^{\circ} \mathrm{S}$. The subtropical circulation cell is closed in the east by the deep Benguela Current (Garzoli and Gordon, 1996; Garzoli et al., 1996) with pulses of more saline Intermediate Water from the Indian Ocean (Agulhas eddies, (Lutjeharms, 1996)) and in the west by the robustly increasing deep Brazil Current (Müller et al., 1996; Zangenberg and Siedler, 1997). It is drained by a narrow, though swift northward Intermediate Western Boundary Current beneath the Brazil Current. This IWBC detaches from the southwestward progressing subtropical gyre return current at the Santos Bifurcation (Boebel et al., 1997a). Farther north this branch is called the North Brazil Undercurrent (Stramma et al., 1995).

The circulation of AAIW north of $30^{\circ} \mathrm{S}$ has been studied in detail by Suga and Talley (1995) using SAVE data. AAIW is recognized as the low-salinity core layer whose depth roughly coincides with the $27.3 \sigma_{\theta}$ surface. Analyzing large-scale hydrographic properties the authors identify two cyclonic circulation cells centered (a) along the line between $19^{\circ} \mathrm{S}$ in the west and $23^{\circ} \mathrm{S}$ in the east and (b) at about $7^{\circ} \mathrm{S}$, being separated by an anticyclone at about $13^{\circ} \mathrm{S}$. Larqué et al. (1997) and Reid (1994), however, identify a single sub-equatorial gyre. The tropical gyre's northern eastward flowing branch is part of the larger equatorial current system. Right at the equator, 
a westward flow is suggested by Suga and Talley, which is in conflict with Reid's analysis. The equatorial current system has been the first to be studied by Lagrangian methods (Richardson and Schmitz, 1993) using SOFAR floats. The resulting trajectories suggested a broad eastward flowing current band, with the considerable transport

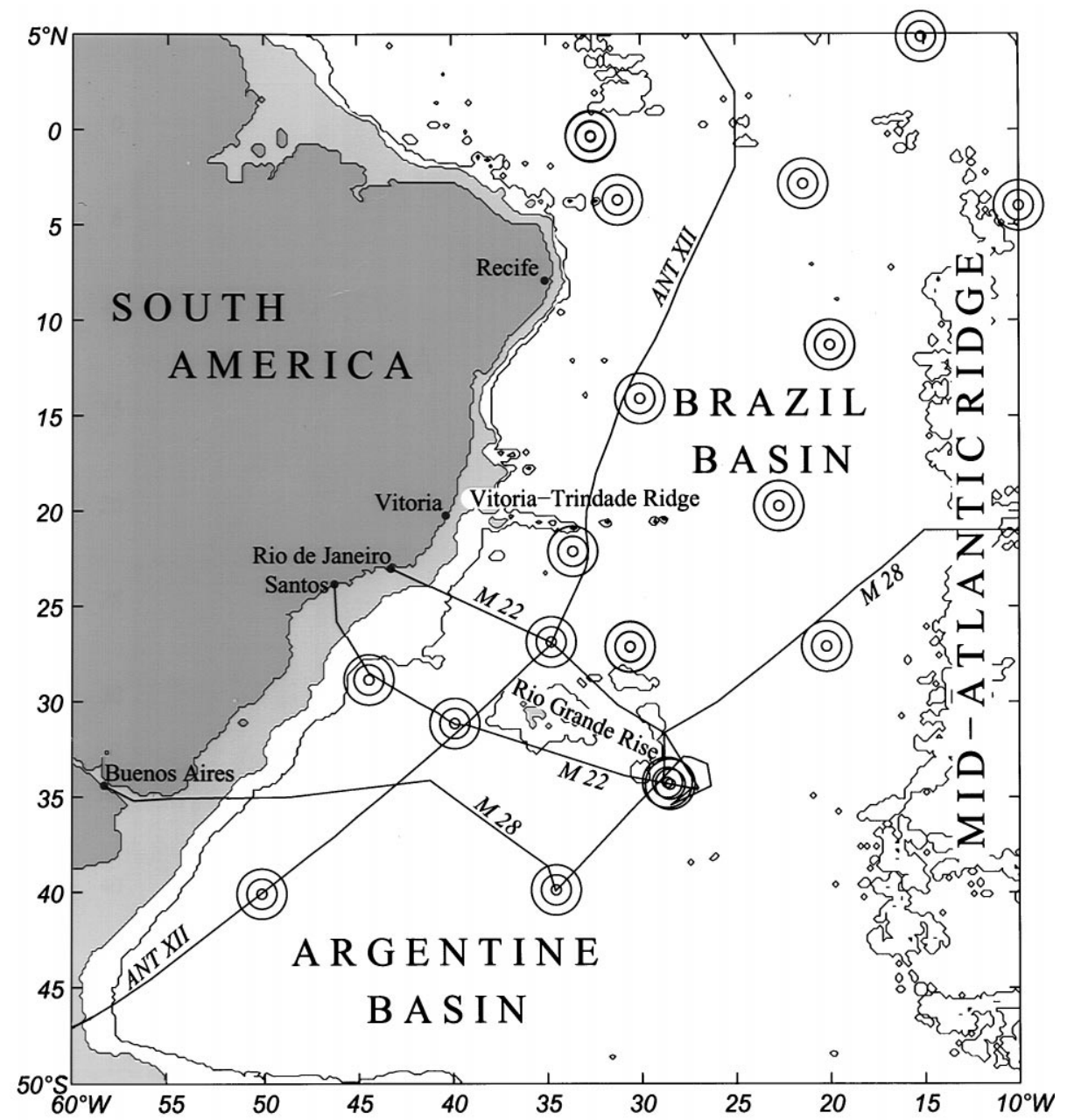

(a)

Fig. 1. (a) Map of the western South Atlantic including topographic features mentioned in the text and cruise tracks of METEOR cruise 22, leg 4 and 28, leg 2 as well as POLARSTERN cruise ANT XII, leg 1. Sound source positions of the joint Deep Basin Experiment (DBE) array are indicated by 3 concentric circles. The South American continent is dark gray, the shelf up to the $1000 \mathrm{~m}$ isobath light gray. An additional isobath at $3000 \mathrm{~m}$ is given. (b) Float trajectories (gray) obtained from RAFOS floats at intermediate depth (see also Table 1). The float launch position is indicated by a dot with the respective float number next to it. Numbers of floats mentioned explicitly in the text that do not appear on other figures are in red. The South American continent is yellow, the shelf up to the $1000 \mathrm{~m}$ isobath light green. 


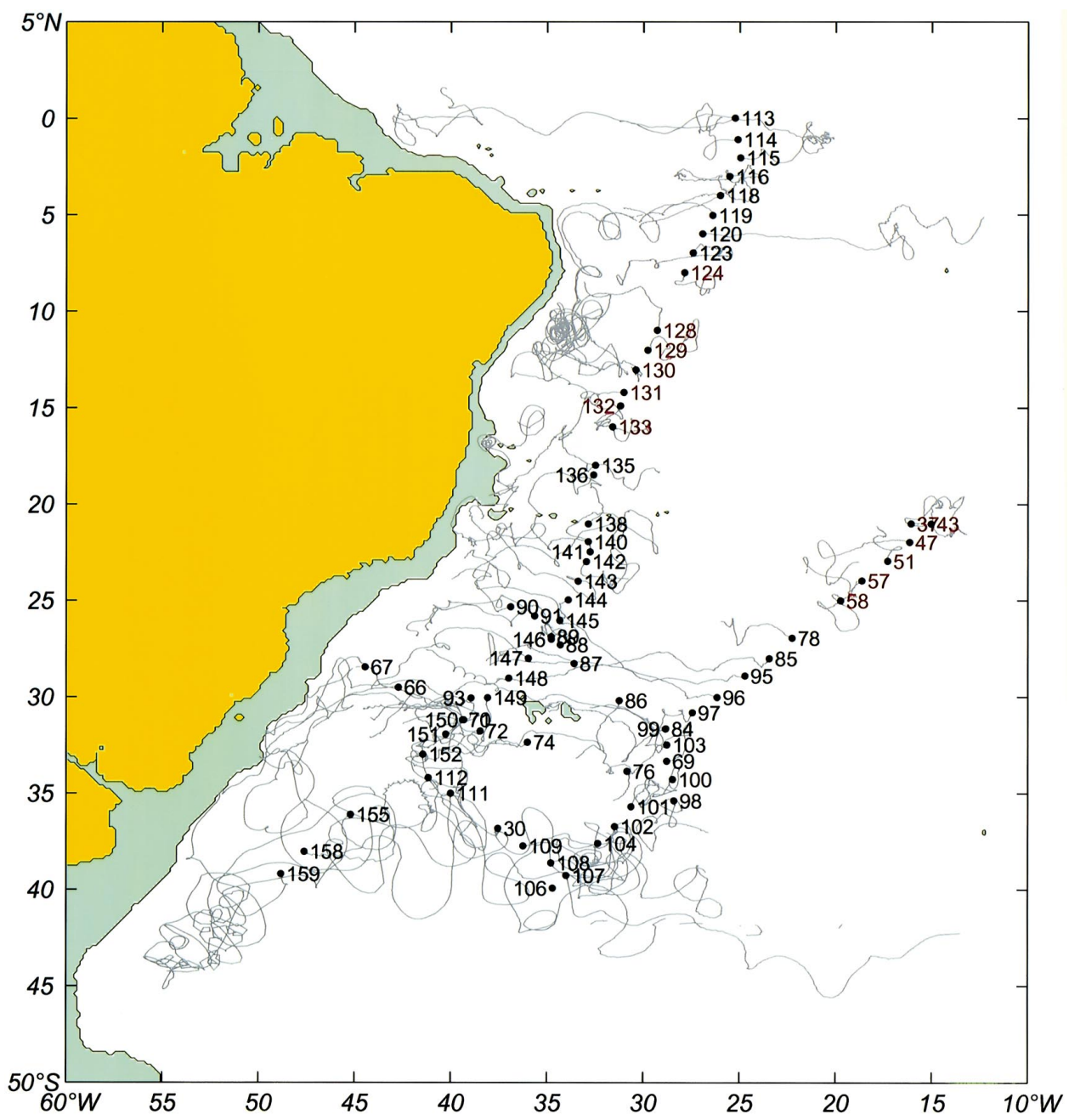

(b)

Fig. 1. Continued.

estimate of $64 \times 10^{6} \mathrm{~m}^{3}$, assuming a continuous eastward flow band. However, Richardson and Schmitz also note a possible alternative explanation, allowing for embedded narrow westward currents that would reduce the total transport and introduce strong horizontal shear.

Recently, more Lagrangian studies were conducted to unravel the South Atlantic circulation at intermediate depth. These studies (Boebel and Schmid, 1995a; Davis et al., 1996; Ollitrault et al., 1994a) used modern float technology such as ALACE (Davis et al., 1992), MARVOR (Ollitrault et al., 1994b) and RAFOS floats (Rossby et al., 1986) to observe directly the advection and diffusion of the intermediate water. A statistical analysis of the combined data sets (Boebel et al., 1997a) gives a 
comprehensive picture of the intermediate flow in the western South Atlantic. With the exception of some details, the results of this statistical analysis are in qualitative agreement with Reid's, Larque's and Talley's hydrographic studies. Most noticeable are a narrow westward equatorial current, a stagnant tropical gyre area, and a protruding subtropical gyre. The latter retains its low salinity by mixing in newly formed AAIW from the Confluence Zone.

This flow pattern is the general framework within which this paper focuses on the mesoscale kinematic elements that contribute to and comprise the mean flow of AAIW. For this purpose it uses the RAFOS floats launched in the western South Atlantic by the float group of the Institut für Meereskunde in Kiel, Germany (IfM-Kiel) between 1994 and 1996. The study covers kinematic elements of the AAIW circulation between the northern Argentine Basin and most of the Brazil Basin.

\section{Experiments and methods}

RAFOS floats are neutrally buoyant, free-drifting instruments, designed to explore deep-sea circulation. Tracking is achieved through the reception of sound signals emitted by moored sound sources, typically on a daily basis. Standard sound sources, moored at the depth of the Sound Fixing and Ranging (SOFAR) channel cover an area of $1000 \mathrm{~km}$ radius or more. In order to provide sound signals within the western South Atlantic, the Woods Hole Oceanographic Institution (WHOI, USA), the Institut für Meereskunde, Kiel (IfM-Kiel, Germany) and IFREMER (Brest, France) joined forces and set up a sound source array of 19 sound sources in total (Fig. 1a). This array enabled us to track floats from the northern equatorial region of the Brazil Basin to the Antarctic Circumpolar Current (ACC) in the southern Argentine Basin. A detailed summary of all floats used in the South Atlantic within the World Ocean Circulation Experiment (WOCE) and related programs is given by Zenk et al. (1998).

The IfM-Kiel contributed the southernmost part of this array, with a total of seven sound sources including one replacement for a lost source. The sources were moored during three cruises: FS METEOR cruise no. 22, leg 3 and 4 (Siedler et al., 1993), FS METEOR cruise no. 28, leg 2 in April-May 1994 (Zenk and Müller, 1995) and FS POLARSTERN cruise ANT-XII leg 1 in October-November 1994 (Boebel and Schmid, 1995b). The latter two of these cruises were dedicated towards RAFOS float experiments, both spanning a large meridional segment. During the three cruises a total of 94 floats, built and ballasted at the IfM-Kiel, were seeded in the AAIW horizon. Over the course of four years, from December 1992 to October 1996 we obtained trajectories of 75 floats (Fig. 1b). The launch and surface data of each instrument are given in Table 1. In total, these trajectories result in 72 float years of data. With respect to the area visited by the floats ( 62 boxes of $5^{\circ}$ by $5^{\circ}$ extension) this equals to $23 \%$ of the WOCE goals ( 5 float years per $5^{\circ}$ by $5^{\circ}$ box) (WCRP, 1988).

During FS METEOR cruise no. 22 (Fig. 1a), a total of 22 floats were seeded around the Rio Grande Rise, but in spite of only one total failure, only 15 trajectories were obtained. The remaining six instruments suffered from leaks, the details of which are described in Boebel et al. (1997b). The second batch of 29 floats, seeded during 
FS METEOR cruise no. 28 between $20^{\circ} \mathrm{S}$ and $40^{\circ} \mathrm{S}$ resulted in 26 trajectories. Two total failures occurred and one float was deaf. During FS POLARSTERN cruise ANT-XII/1 a total of 42 floats were seeded from the equator to $40^{\circ} \mathrm{S}$, parallel to the South American coast at approximately $1000 \mathrm{~km}$ distance from the shelf break. Probably imperfectly polished terminals of the pressure glass housing caused eight total failures within this batch, resulting in 34 trajectories.

Nevertheless, the overall efficiency was increased steadily during these experiments. Due to a continuous extension of the pre-programmed mission length, the average endurance per batch rose from 116 days (FS METEOR cruise 22) to 322 days (FS METEOR cruise 28) to finally 340 days (FS POLARSTERN cruise ANT XII). These numbers include total failures, each entering the statistics as zero days endurance. Similarly, the maximum achieved endurance increased from 360 days, to 540 days and finally to 720 days, respectively. The demand for longer missions with its benefit of higher average endurance, however, increases the risk of total failures due to corrosion or low batteries. This might have been a contributing factor to the loss of eight floats within the last batch.

In order to make a float neutrally buoyant at a given depth, its density has to be adjusted, such that under consideration of the floats' compressibility and coefficient of thermal expansion, the float density matches the water density at target depth. Our goal was to seed the floats at the salinity minimum of the AAIW. Since the depth of this minimum changes with position and possibly over time, in situ CTD stations provided density profiles at the planned float launch positions. From these in situ data the float density was adjusted onboard just before launch. In Fig. 2 each initial float position (as obtained from its first valid pressure record) is projected on a combined salinity/density section taken during the POLARSTERN cruise ANT XII (Fig. 1a). Clearly our task was well achieved, with the floats indeed occupying the AAIW salinity minimum layer.

\section{Results and discussion}

\subsection{Equatorial jets and their variability}

The fundamental questions of the location, magnitude and stability of the AAIW cross equatorial flow have found the attention of many oceanographic studies. The results, however, continue to be ambiguous, especially regarding the continuous westward flow of an Equatorial Intermediate Current ${ }^{1}$ (EIC) along the equator. Reid (1994), for example, presents maps of adjusted steric height that show an eastward flow at 800 dbar (his Fig. 8d) and 1000 dbar (his Fig. 8e) in the area between $7^{\circ} \mathrm{S}$ and slightly north of or at equator, but contrasting results are presented by Talley (1996).

\footnotetext{
${ }^{1}$ In this context we define the Equatorial Intermediate Current as the flow between $1^{\circ} \mathrm{N}$ and $1^{\circ} \mathrm{S}$. The depth is obviously defined by the depth of the observing platform, which was restricted to the pressure range of 650-1050 dbar in the case of our floats, but which might differ from this in the data taken from the literature.
} 
Table 1

Dates and positions of RAFOS float launch and surface sites

\begin{tabular}{|c|c|c|c|c|c|c|c|}
\hline \multirow[t]{2}{*}{ Float } & \multicolumn{3}{|l|}{ Launch } & \multicolumn{3}{|l|}{ Surface } & \multirow{2}{*}{$\begin{array}{l}\text { Pressure range } \\
\text { (dbar) }\end{array}$} \\
\hline & Date & Latitude & Longitude & Date & Latitude & Longitude & \\
\hline 30 & 09.06 .94 & $36^{\circ} 48.38^{\prime} \mathrm{S}$ & $37^{\circ} 31.32^{\prime} \mathrm{W}$ & 08.09 .94 & $34^{\circ} 44.88^{\prime} \mathrm{S}$ & $40^{\circ} 56.04^{\prime} \mathrm{W}$ & $923.0-960.5$ \\
\hline 37 & 21.05 .94 & $20^{\circ} 59.53^{\prime} \mathrm{S}$ & $15^{\circ} 01.07^{\prime} \mathrm{W}$ & 11.11 .95 & $21^{\circ} 33.18^{\prime} \mathrm{S}$ & $13^{\circ} 09.00^{\prime} \mathrm{W}$ & 788.9-1025.7 \\
\hline 43 & 21.05 .94 & $20^{\circ} 59.53^{\prime} \mathrm{S}$ & $15^{\circ} 01.07^{\prime} \mathrm{W}$ & 15.04 .95 & $20^{\circ} 46.50^{\prime} \mathrm{S}$ & $13^{\circ} 56.94^{\prime} \mathrm{W}$ & $764.8-893.8$ \\
\hline 47 & 22.05 .94 & $21^{\circ} 59.91^{\prime} \mathrm{S}$ & $16^{\circ} 09.02^{\prime} \mathrm{W}$ & 13.08 .95 & $22^{\circ} 59.88^{\prime} \mathrm{S}$ & $18^{\circ} 47.88^{\prime} \mathrm{W}$ & $781.2-841.2$ \\
\hline 51 & 22.05 .94 & $22^{\circ} 59.95^{\prime} \mathrm{S}$ & $17^{\circ} 16.98^{\prime} \mathrm{W}$ & 16.03 .95 & $21^{\circ} 10.38^{\prime} \mathrm{S}$ & $17^{\circ} 52.56^{\prime} \mathrm{W}$ & $827.3-859.4$ \\
\hline 57 & 23.05 .94 & $23^{\circ} 59.98^{\prime} \mathrm{S}$ & $18^{\circ} 35.99^{\prime} \mathrm{W}$ & 16.04 .95 & $23^{\circ} 36.84^{\prime} \mathrm{S}$ & $21^{\circ} 32.82^{\prime} \mathrm{W}$ & $810.6-863.4$ \\
\hline 58 & 23.05 .94 & $24^{\circ} 59.90^{\prime} \mathrm{S}$ & $19^{\circ} 44.00^{\prime} \mathrm{W}$ & 15.06 .95 & $24^{\circ} 01.92^{\prime} \mathrm{S}$ & $34^{\circ} 03.54^{\prime} \mathrm{W}$ & $843.4-901.1$ \\
\hline 66 & 04.12 .92 & $29^{\circ} 30.87^{\prime} \mathrm{S}$ & $42^{\circ} 42.14^{\prime} \mathrm{W}$ & 03.03 .93 & $31^{\circ} 38.40^{\prime} \mathrm{S}$ & $47^{\circ} 11.07^{\prime} \mathrm{W}$ & $767.3-808.3$ \\
\hline 67 & 03.12 .92 & $28^{\circ} 27.08^{\prime} \mathrm{S}$ & $44^{\circ} 27.68^{\prime} \mathrm{W}$ & 29.08 .93 & $32^{\circ} 23.34^{\prime} \mathrm{S}$ & $48^{\circ} 06.66^{\prime} \mathrm{W}$ & $828.4-1259.3$ \\
\hline 69 & 27.05 .94 & $33^{\circ} 22.54^{\prime} \mathrm{S}$ & $28^{\circ} 48.84^{\prime} \mathrm{W}$ & 19.06.95 & $33^{\circ} 10.38^{\prime} \mathrm{S}$ & $33^{\circ} 30.60^{\prime} \mathrm{W}$ & 966.9-1028.8 \\
\hline 70 & 08.12 .92 & $31^{\circ} 11.96^{\prime} \mathrm{S}$ & $39^{\circ} 21.04^{\prime} \mathrm{W}$ & 04.06 .93 & $32^{\circ} 01.98^{\prime} \mathrm{S}$ & $44^{\circ} 09.48^{\prime} \mathrm{W}$ & $825.6-1313.7$ \\
\hline 71 & 08.12 .92 & $31^{\circ} 11.82^{\prime} \mathrm{S}$ & $39^{\circ} 21.09^{\prime} \mathrm{W}$ & 22.01 .93 & $30^{\circ} 18.42^{\prime} \mathrm{S}$ & $40^{\circ} 51.24^{\prime} \mathrm{W}$ & $779.4-1347.1$ \\
\hline 72 & 09.12 .92 & $31^{\circ} 39.97^{\prime} \mathrm{S}$ & $37^{\circ} 45.17^{\prime} \mathrm{W}$ & 08.03 .93 & $31^{\circ} 25.26^{\prime} \mathrm{S}$ & $42^{\circ} 29.34^{\prime} \mathrm{W}$ & $897.5-1114.8$ \\
\hline 74 & 09.12.92 & $32^{\circ} 13.94^{\prime} \mathrm{S}$ & $35^{\circ} 50.03^{\prime} \mathrm{W}$ & 28.10 .93 & $31^{\circ} 02.04^{\prime} \mathrm{S}$ & $44^{\circ} 10.32^{\prime} \mathrm{W}$ & $813.3-951$ \\
\hline 76 & 11.12 .92 & $33^{\circ} 51.09^{\prime} \mathrm{S}$ & $30^{\circ} 53.56^{\prime} \mathrm{W}$ & 09.03 .93 & $35^{\circ} 20.88^{\prime} \mathrm{S}$ & $31^{\circ} 35.40^{\prime} \mathrm{W}$ & $911.1-954.7$ \\
\hline 78 & 24.05 .94 & $26^{\circ} 59.69^{\prime} \mathrm{S}$ & $22^{\circ} 09.92^{\prime} \mathrm{W}$ & 17.04 .95 & $26^{\circ} 04.98^{\prime} \mathrm{S}$ & $25^{\circ} 56.46^{\prime} \mathrm{W}$ & $847.6-901.5$ \\
\hline 84 & 16.12 .92 & $31^{\circ} 38.06^{\prime} \mathrm{S}$ & $28^{\circ} 47.61^{\prime} \mathrm{W}$ & 15.03 .93 & $30^{\circ} 33.90^{\prime} \mathrm{S}$ & $32^{\circ} 46.56^{\prime} \mathrm{W}$ & $791.8-834.4$ \\
\hline 85 & 24.05 .94 & $27^{\circ} 59.93^{\prime} \mathrm{S}$ & $23^{\circ} 24.94^{\prime} \mathrm{W}$ & 14.11 .95 & $28^{\circ} 59.22^{\prime} \mathrm{S}$ & $37^{\circ} 36.72^{\prime} \mathrm{W}$ & $865.9-930.2$ \\
\hline 86 & 17.12.92 & $30^{\circ} 10.55^{\prime} \mathrm{S}$ & $31^{\circ} 15.02^{\prime} \mathrm{W}$ & 12.11 .93 & $31^{\circ} 57.96^{\prime} \mathrm{S}$ & $41^{\circ} 12.30^{\prime} \mathrm{W}$ & $824.4-940.5$ \\
\hline 87 & 18.12 .92 & $28^{\circ} 17.80^{\prime} \mathrm{S}$ & $33^{\circ} 30.10^{\prime} \mathrm{W}$ & 16.03 .93 & $27^{\circ} 07.62^{\prime} \mathrm{S}$ & $35^{\circ} 53.40^{\prime} \mathrm{W}$ & $794.3-1355.3$ \\
\hline 88 & 18.12 .92 & $27^{\circ} 22.93^{\prime} \mathrm{S}$ & $34^{\circ} 14.35^{\prime} \mathrm{W}$ & 15.01 .93 & $26^{\circ} 56.00^{\prime} \mathrm{S}$ & $34^{\circ} 16.80^{\prime} \mathrm{W}$ & 838.2-978.8 \\
\hline 89 & 19.12.92 & $26^{\circ} 52.99^{\prime} \mathrm{S}$ & $34^{\circ} 47.43^{\prime} \mathrm{W}$ & 17.03 .93 & $26^{\circ} 27.00^{\prime} \mathrm{S}$ & $34^{\circ} 42.36^{\prime} \mathrm{W}$ & $785.7-848.5$ \\
\hline 90 & 19.12.92 & $25^{\circ} 21.49^{\prime} \mathrm{S}$ & $36^{\circ} 54.49^{\prime} \mathrm{W}$ & 16.06 .93 & $23^{\circ} 55.32^{\prime} \mathrm{S}$ & $39^{\circ} 59.40^{\prime} \mathrm{W}$ & $738.1-794.8$ \\
\hline 91 & 19.12 .92 & $25^{\circ} 49.80^{\prime} \mathrm{S}$ & $35^{\circ} 40.10^{\prime} \mathrm{W}$ & 12.12 .93 & $26^{\circ} 27.06^{\prime} \mathrm{S}$ & $41^{\circ} 13.08^{\prime} \mathrm{W}$ & $847.4-1207.3$ \\
\hline 93 & 04.01 .93 & $30^{\circ} 01.10^{\prime} \mathrm{S}$ & $38^{\circ} 54.70^{\prime} \mathrm{W}$ & 08.05 .93 & $30^{\circ} 42.48^{\prime} \mathrm{S}$ & $44^{\circ} 12.24^{\prime} \mathrm{W}$ & $802.4-826.7$ \\
\hline 95 & 25.05 .94 & $28^{\circ} 59.84^{\prime} \mathrm{S}$ & $24^{\circ} 41.93^{\prime} \mathrm{W}$ & 19.03 .95 & $25^{\circ} 40.32^{\prime} \mathrm{S}$ & $34^{\circ} 03.72^{\prime} \mathrm{W}$ & $904.0-970.0$ \\
\hline 96 & 25.05 .94 & $29^{\circ} 59.93^{\prime} \mathrm{S}$ & $25^{\circ} 58.14^{\prime} \mathrm{W}$ & 19.04 .95 & $28^{\circ} 07.98^{\prime} \mathrm{S}$ & $38^{\circ} 13.14^{\prime} \mathrm{W}$ & 918.1-1009.1 \\
\hline 97 & 26.05 .94 & $30^{\circ} 48.93^{\prime} \mathrm{S}$ & $27^{\circ} 48.93^{\prime} \mathrm{W}$ & 17.08 .95 & $27^{\circ} 32.64^{\prime} \mathrm{S}$ & $41^{\circ} 18.18^{\prime} \mathrm{W}$ & $957.8-1045.6$ \\
\hline 98 & 01.06 .94 & $35^{\circ} 25.21^{\prime} \mathrm{S}$ & $28^{\circ} 22.13^{\prime} \mathrm{W}$ & 21.04 .95 & $36^{\circ} 57.54^{\prime} \mathrm{S}$ & $26^{\circ} 35.28^{\prime} \mathrm{W}$ & $996.4-1086.5$ \\
\hline 99 & 26.05 .94 & $31^{\circ} 37.38^{\prime} \mathrm{S}$ & $28^{\circ} 49.18^{\prime} \mathrm{W}$ & 21.03 .95 & $30^{\circ} 50.52^{\prime} \mathrm{S}$ & $34^{\circ} 53.22^{\prime} \mathrm{W}$ & $910.2-971.5$ \\
\hline 100 & 27.05 .94 & $34^{\circ} 19.14^{\prime} \mathrm{S}$ & $28^{\circ} 29.72^{\prime} \mathrm{W}$ & 22.03 .95 & $34^{\circ} 31.74^{\prime} \mathrm{S}$ & $29^{\circ} 18.54^{\prime} \mathrm{W}$ & 978.6-1018.8 \\
\hline 101 & 06.06 .94 & $35^{\circ} 47.01^{\prime} \mathrm{S}$ & $30^{\circ} 39.54^{\prime} \mathrm{W}$ & 19.11.95 & $35^{\circ} 29.94^{\prime} \mathrm{S}$ & $29^{\circ} 06.00^{\prime} \mathrm{W}$ & $946.7-1002.9$ \\
\hline 102 & 06.06 .94 & $36^{\circ} 42.16^{\prime} \mathrm{S}$ & $31^{\circ} 30.51^{\prime} \mathrm{W}$ & 24.03 .95 & $38^{\circ} 38.22^{\prime} \mathrm{S}$ & $32^{\circ} 43.56^{\prime} \mathrm{W}$ & $977.4-1019.5$ \\
\hline 103 & 26.05 .94 & $32^{\circ} 30.05^{\prime} \mathrm{S}$ & $28^{\circ} 48.14^{\prime} \mathrm{W}$ & 05.11 .94 & $31^{\circ} 04.80^{\prime} \mathrm{S}$ & $30^{\circ} 01.92^{\prime} \mathrm{W}$ & $1063.7-1337.9$ \\
\hline 104 & 06.06 .94 & $37^{\circ} 36.64^{\prime} \mathrm{S}$ & $32^{\circ} 21.95^{\prime} \mathrm{W}$ & 30.04 .95 & $41^{\circ} 28.08^{\prime} \mathrm{S}$ & $28^{\circ} 40.32^{\prime} \mathrm{W}$ & Pres. sens. defect \\
\hline 106 & 07.06 .94 & $39^{\circ} 54.17^{\prime} \mathrm{S}$ & $34^{\circ} 34.77^{\prime} \mathrm{W}$ & 03.05 .95 & $42^{\circ} 00.90^{\prime} \mathrm{S}$ & $15^{\circ} 58.74^{\prime} \mathrm{W}$ & 704.7-848.8 \\
\hline 107 & 07.06.94 & $39^{\circ} 25.90^{\prime} \mathrm{S}$ & $34^{\circ} 06.01^{\prime} \mathrm{W}$ & 02.04 .95 & $44^{\circ} 24.42^{\prime} \mathrm{S}$ & $09^{\circ} 14.88^{\prime} \mathrm{W}$ & $702.0-764.8$ \\
\hline 108 & 08.06 .94 & $38^{\circ} 36.60^{\prime} \mathrm{S}$ & $34^{\circ} 58.67^{\prime} \mathrm{W}$ & 02.07.95 & $39^{\circ} 04.44^{\prime} \mathrm{S}$ & $26^{\circ} 40.80^{\prime} \mathrm{W}$ & $766.3-821.6$ \\
\hline 109 & 08.06 .94 & $37^{\circ} 42.79^{\prime} \mathrm{S}$ & $36^{\circ} 15.51^{\prime} \mathrm{W}$ & 03.04 .95 & $37^{\circ} 02.22^{\prime} \mathrm{S}$ & $31^{\circ} 56.34^{\prime} \mathrm{W}$ & $989.3-1046.1$ \\
\hline 111 & 09.06 .94 & $35^{\circ} 00.15^{\prime} \mathrm{S}$ & $40^{\circ} 00.10^{\prime} \mathrm{W}$ & 04.04 .95 & $38^{\circ} 03.72^{\prime} \mathrm{S}$ & $31^{\circ} 30.30^{\prime} \mathrm{W}$ & $886.8-955.8$ \\
\hline 112 & 10.06.94 & $34^{\circ} 05.74^{\prime} \mathrm{S}$ & $41^{\circ} 13.30^{\prime} \mathrm{W}$ & 03.07.95 & $37^{\circ} 51.66^{\prime} \mathrm{S}$ & $38^{\circ} 20.58^{\prime} \mathrm{W}$ & 927.1-990.1 \\
\hline 113 & 02.11 .94 & $00^{\circ} 00.20^{\prime} \mathrm{N}$ & $25^{\prime} 00.10^{\prime} \mathrm{W}$ & 25.10 .95 & $01^{\circ} 29.28^{\prime} \mathrm{N}$ & $40^{\circ} 18.72^{\prime} \mathrm{W}$ & $740.6-870.2$ \\
\hline 114 & 02.11 .94 & $01^{\circ} 00.00^{\prime} \mathrm{S}$ & $24^{\circ} 59.94^{\prime} \mathrm{W}$ & 24.05 .95 & $00^{\circ} 02.94^{\prime} \mathrm{N}$ & $25^{\circ} 55.92^{\prime} \mathrm{W}$ & $772.0-805.5$ \\
\hline 115 & 02.11 .94 & $01^{\circ} 59.90^{\prime} \mathrm{S}$ & $25^{\circ} 00.00^{\prime} \mathrm{W}$ & 25.10 .95 & $00^{\circ} 07.98^{\prime} \mathrm{S}$ & $31^{\circ} 12.72^{\prime} \mathrm{W}$ & $758.5-807.7$ \\
\hline 116 & 02.11 .94 & $03^{\circ} 00.10^{\prime} \mathrm{S}$ & $25^{\circ} 28.70^{\prime} \mathrm{W}$ & 21.07 .96 & $04^{\circ} 36.66^{\prime} \mathrm{S}$ & $31^{\circ} 01.62^{\prime} \mathrm{W}$ & $749.5-805.6$ \\
\hline 118 & 03.11 .94 & $03^{\circ} 59.90^{\prime} \mathrm{S}$ & $25^{\circ} 57.20^{\prime} \mathrm{W}$ & 25.10 .95 & $10^{\circ} 33.06^{\prime} \mathrm{S}$ & $34^{\circ} 28.38^{\prime} \mathrm{W}$ & $795.0-830.8$ \\
\hline 119 & 03.11 .94 & $05^{\circ} 00.20^{\prime} \mathrm{S}$ & $26^{\circ} 26.40^{\prime} \mathrm{W}$ & 23.01 .96 & $10^{\circ} 28.20^{\prime} \mathrm{S}$ & $34^{\circ} 02.16^{\prime} \mathrm{W}$ & $777.5-864.1$ \\
\hline
\end{tabular}


Table 1. Continued.

\begin{tabular}{|c|c|c|c|c|c|c|c|}
\hline \multirow[t]{2}{*}{ Float } & \multicolumn{3}{|l|}{ Launch } & \multicolumn{3}{|l|}{ Surface } & \multirow{2}{*}{$\begin{array}{l}\text { Pressure range } \\
\text { (dbar) }\end{array}$} \\
\hline & Date & Latitude & Longitude & Date & Latitude & Longitude & \\
\hline 120 & 03.11 .94 & $06^{\circ} 00.00^{\prime} \mathrm{S}$ & $26^{\circ} 55.20^{\prime} \mathrm{W}$ & 25.10 .95 & $05^{\circ} 02.16^{\prime} \mathrm{S}$ & $12^{\circ} 18.42^{\prime} \mathrm{W}$ & $847.4-888.0$ \\
\hline 123 & 03.11 .94 & $07^{\circ} 00.20^{\prime} \mathrm{S}$ & $27^{\circ} 24.20^{\prime} \mathrm{W}$ & 22.04 .96 & $08^{\circ} 38.94^{\prime} \mathrm{N}$ & $31^{\circ} 07.26^{\prime} \mathrm{W}$ & $856.5-1135.7$ \\
\hline 124 & 04.11 .94 & $08^{\circ} 00.10^{\prime} \mathrm{S}$ & $27^{\circ} 53.30^{\prime} \mathrm{W}$ & 28.10 .95 & $09^{\circ} 07.50^{\prime} \mathrm{S}$ & $26^{\circ} 40.98^{\prime} \mathrm{W}$ & $854.2-899.2$ \\
\hline 128 & 05.11 .94 & $11^{\circ} 00.10^{\prime} \mathrm{S}$ & $29^{\circ} 13.50^{\prime} \mathrm{W}$ & 22.10 .96 & $08^{\circ} 31.38^{\prime} \mathrm{S}$ & $33^{\circ} 04.68^{\prime} \mathrm{W}$ & $792.6-1364.1$ \\
\hline 129 & 05.11 .94 & $12^{\circ} 00.00^{\prime} \mathrm{S}$ & $29^{\circ} 48.00^{\prime} \mathrm{W}$ & 29.10 .95 & $12^{\circ} 06.30^{\prime} \mathrm{S}$ & $27^{\circ} 58.38^{\prime} \mathrm{W}$ & $811.9-854.7$ \\
\hline 130 & 05.11 .94 & $13^{\circ} 00.10^{\prime} \mathrm{S}$ & $30^{\circ} 24.00^{\prime} \mathrm{W}$ & 27.01 .96 & $12^{\circ} 41.22^{\prime} \mathrm{S}$ & $34^{\circ} 19.38^{\prime} \mathrm{W}$ & $735.6-1052.7$ \\
\hline 131 & 06.11 .94 & $14^{\circ} 15.00^{\prime} \mathrm{S}$ & $31^{\circ} 00.00^{\prime} \mathrm{W}$ & 28.11 .95 & $13^{\circ} 04.08^{\prime} \mathrm{S}$ & $30^{\circ} 52.02^{\prime} \mathrm{W}$ & $735.8-774.0$ \\
\hline 132 & 06.11 .94 & $15^{\circ} 00.22^{\prime} \mathrm{S}$ & $31^{\circ} 11.60^{\prime} \mathrm{W}$ & 27.01 .96 & $16^{\circ} 18.06^{\prime} \mathrm{S}$ & $33^{\circ} 43.92^{\prime} \mathrm{W}$ & $763.0-1021.5$ \\
\hline 133 & 06.11 .94 & $16^{\circ} 00.06^{\prime} \mathrm{S}$ & $31^{\circ} 35.65^{\prime} \mathrm{W}$ & 31.10 .95 & $15^{\circ} 54.42^{\prime} \mathrm{S}$ & $32^{\circ} 26.58^{\prime} \mathrm{W}$ & $750.8-861.9$ \\
\hline 135 & 07.11 .94 & $18^{\circ} 00.18^{\prime} \mathrm{S}$ & $32^{\circ} 23.92^{\prime} \mathrm{W}$ & 30.11 .95 & $15^{\circ} 42.36^{\prime} \mathrm{S}$ & $36^{\circ} 35.28^{\prime} \mathrm{W}$ & $763.1-856.0$ \\
\hline 136 & 07.11 .94 & $18^{\circ} 30.00^{\prime} \mathrm{S}$ & $32^{\circ} 30.00^{\prime} \mathrm{W}$ & 17.09 .95 & $18^{\circ} 22.80^{\prime} \mathrm{S}$ & $29^{\circ} 18.12^{\prime} \mathrm{W}$ & $764.4-1366.2$ \\
\hline 138 & 08.11 .94 & $21^{\circ} 00.09^{\prime} \mathrm{S}$ & $32^{\circ} 55.70^{\prime} \mathrm{W}$ & 30.01 .96 & $19^{\circ} 15.24^{\prime} \mathrm{S}$ & $36^{\circ} 24.30^{\prime} \mathrm{W}$ & $786.1-1376.40$ \\
\hline 140 & 08.11 .94 & $22^{\circ} 00.50^{\prime} \mathrm{S}$ & $32^{\circ} 48.52^{\prime} \mathrm{W}$ & 29.04 .96 & $23^{\circ} 52.08^{\prime} \mathrm{S}$ & $38^{\circ} 41.82^{\prime} \mathrm{W}$ & $822.0-1152.6$ \\
\hline 141 & 09.11 .94 & $22^{\circ} 30.00^{\prime} \mathrm{S}$ & $32^{\circ} 50.00^{\prime} \mathrm{W}$ & 01.11 .95 & $20^{\circ} 49.02^{\prime} \mathrm{S}$ & $38^{\circ} 31.08^{\prime} \mathrm{W}$ & $851.9-892.4$ \\
\hline 142 & 09.11 .94 & $23^{\circ} 00.10^{\prime} \mathrm{S}$ & $32^{\circ} 56.86^{\prime} \mathrm{W}$ & 01.02 .96 & $23^{\circ} 51.84^{\prime} \mathrm{S}$ & $30^{\circ} 47.82^{\prime} \mathrm{W}$ & $848.4-1372.2$ \\
\hline 143 & 09.11 .94 & $24^{\circ} 00.20^{\prime} \mathrm{S}$ & $33^{\circ} 24.70^{\prime} \mathrm{W}$ & 03.12 .95 & $22^{\circ} 42.60^{\prime} \mathrm{S}$ & $37^{\circ} 38.52^{\prime} \mathrm{W}$ & $846.4-1163.1$ \\
\hline 144 & 10.11 .94 & $25^{\circ} 00.08^{\prime} \mathrm{S}$ & $33^{\circ} 53.00^{\prime} \mathrm{W}$ & 12.11 .95 & $22^{\circ} 50.10^{\prime} \mathrm{S}$ & $39^{\circ} 22.14^{\prime} \mathrm{W}$ & $783.1-1364.3$ \\
\hline 145 & 10.11 .94 & $26^{\circ} 00.10^{\prime} \mathrm{S}$ & $34^{\circ} 21.60^{\prime} \mathrm{W}$ & 03.11 .95 & $28^{\circ} 05.40^{\prime} \mathrm{S}$ & $37^{\circ} 37.80^{\prime} \mathrm{W}$ & $861.1-901.3$ \\
\hline 146 & 10.11 .94 & $27^{\circ} 00.00^{\prime} \mathrm{S}$ & $34^{\circ} 47.60^{\prime} \mathrm{W}$ & 01.02 .96 & $26^{\circ} 46.44^{\prime} \mathrm{S}$ & $41^{\circ} 46.44^{\prime} \mathrm{W}$ & $868.4-972.3$ \\
\hline 147 & 11.11 .94 & $28^{\circ} 00.10^{\prime} \mathrm{S}$ & $35^{\circ} 56.90^{\prime} \mathrm{W}$ & 03.12 .95 & $29^{\circ} 36.18^{\prime} \mathrm{S}$ & $44^{\circ} 07.26^{\prime} \mathrm{W}$ & $867.1-899.7$ \\
\hline 148 & 11.11.94 & $29^{\circ} 00.20^{\prime} \mathrm{S}$ & $36^{\circ} 59.90^{\prime} \mathrm{W}$ & 02.05 .96 & $33^{\circ} 04.44^{\prime} \mathrm{S}$ & $41^{\circ} 49.20^{\prime} \mathrm{W}$ & $972.8-1031.7$ \\
\hline 149 & 11.11.94 & $30^{\circ} 00.30^{\prime} \mathrm{S}$ & $38^{\circ} 02.90^{\prime} \mathrm{W}$ & 04.11 .95 & $34^{\circ} 41.04^{\prime} \mathrm{S}$ & $39^{\circ} 40.74^{\prime} \mathrm{W}$ & $867.1-899.7$ \\
\hline 150 & 12.11 .94 & $31^{\circ} 12.30^{\prime} \mathrm{S}$ & $39^{\circ} 21.50^{\prime} \mathrm{W}$ & 02.02 .96 & $35^{\circ} 04.68^{\prime} \mathrm{S}$ & $43^{\circ} 57.96^{\prime} \mathrm{W}$ & $828.4-996.2$ \\
\hline 151 & 12.11 .94 & $31^{\circ} 59.90^{\prime} \mathrm{S}$ & $40^{\circ} 15.90^{\prime} \mathrm{W}$ & 04.12 .95 & $31^{\circ} 41.52^{\prime} \mathrm{S}$ & $49^{\circ} 31.74^{\prime} \mathrm{W}$ & $930.0-997.8$ \\
\hline 152 & 12.11 .94 & $33^{\circ} 00.06^{\prime} \mathrm{S}$ & $41^{\circ} 15.90^{\prime} \mathrm{W}$ & 02.08 .96 & $35^{\circ} 18.06^{\prime} \mathrm{S}$ & $47^{\circ} 38.2^{\prime} \mathrm{W}$ & $867.2-1337.8$ \\
\hline 155 & 14.11.94 & $36^{\circ} 00.20^{\prime} \mathrm{S}$ & $45^{\circ} 04.80^{\prime} \mathrm{W}$ & 06.12 .95 & $41^{\circ} 35.82^{\prime} \mathrm{S}$ & $52^{\circ} 33.96^{\prime} \mathrm{W}$ & $685.1-953.7$ \\
\hline 158 & 14.11.94 & $38^{\circ} 00.30^{\prime} \mathrm{S}$ & $47^{\circ} 34.66^{\prime} \mathrm{W}$ & 07.11 .95 & $32^{\circ} 43.68^{\prime} \mathrm{S}$ & $40^{\circ} 35.94^{\prime} \mathrm{W}$ & $605.1-701.4$ \\
\hline 159 & 15.11 .94 & $39^{\circ} 00.20^{\prime} \mathrm{S}$ & $48^{\circ} 51.20^{\prime} \mathrm{W}$ & 05.02 .96 & $37^{\circ} 47.16^{\prime} \mathrm{S}$ & $32^{\circ} 28.08^{\prime} \mathrm{W}$ & $647.4-1375.4$ \\
\hline
\end{tabular}

In a similar study on a shallower isopycnal $\left(27.1 \sigma_{\theta}\right.$ or $31.7 \sigma_{1}$, which corresponds to 500 dbar at the equator) maps of pressure anomaly streamfunction lead Talley to conclude a "westward flow right along the equator and eastward flow to the south".

Early current meter observations at the equator between $1.5^{\circ} \mathrm{N}$ and $1.5^{\circ} \mathrm{S}$ (Stalcup and Metcalf, 1966) reported a westward flow at $405 \mathrm{~m}$ depth below the permanent eastward Equatorial Undercurrent. The observed westward mean velocity reached a maximum of $25 \mathrm{~cm} \mathrm{~s}^{-1}$ approximately $30 \mathrm{~nm}(56 \mathrm{~km})$ north of the equator. Additional direct observations of equatorial westward flow at the AAIW level can be found in mooring data from the Global Atmospheric Research Programme Atlantic Tropical Experiment (GATE). Weisberg (1980) reports two short-term records at $700 \mathrm{~m}$ from the equator $(30 \mathrm{~d})$ and at $1^{\circ} \mathrm{S}(63 \mathrm{~d})$ in the eastern basin $\left(10^{\circ} \mathrm{W}\right)$ during 1974 . The record from the equator shows a persistent westward flow of $O\left(18 \mathrm{~cm} \mathrm{~s}^{-1}\right)$, while the current recorded at $1^{\circ} \mathrm{S} 10^{\circ} \mathrm{W}$ gives more fluctuations with a westward mean flow 


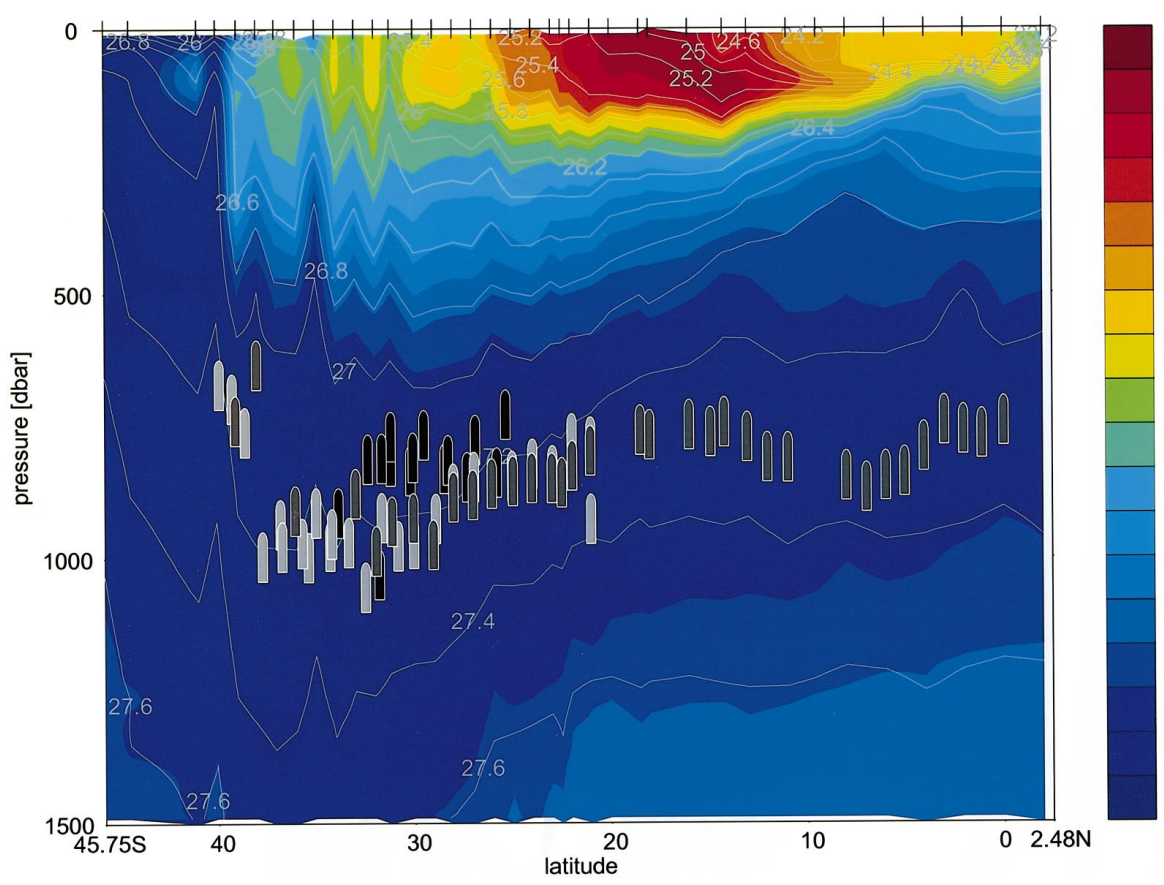

Fig. 2. Section of salinity (color code) taken during October-November 1994 with projected float launch positions. The section follows the course track of POLARSTERN cruise ANT XII, leg 1, as given in Fig. 1a. Isopycnals $\left(\sigma_{\theta}\right)$ are superposed as gray lines. The positions of float launches at the corresponding depths (measured after the float reached neutral buoyancy) are indicated by black, light and dark gray float symbols for Meteor cruise $22 \& 28$ and POLARSTERN cruise ANT XII, respectively.

similar to the one observed at the equator. Farther to the west, along $26^{\circ}-28^{\circ} \mathrm{W}$, instruments were moored at 500 and $1000 \mathrm{~m}$ (Weisberg et al., 1980). In this measurement, however, the mean zonal component from the equator at $487 \mathrm{~m}$ was eastward at $8.5 \mathrm{~cm} \mathrm{~s}^{-1}$ during July 1974 . The off-equator records at $26^{\circ}-28^{\circ} \mathrm{W}$ of about equal length show a slight eastward drift between 500 and $1050 \mathrm{~m}$ depth.

In a study of the western boundary regime Schott et al. (1995) have investigated currents of the warmwater sphere between $10^{\circ} \mathrm{S}$ and $10^{\circ} \mathrm{N}$ in equatorial regions west of $30^{\circ} \mathrm{W}$. Their analysis includes an intermediate layer bound by $26.8 \sigma_{\theta}$ at the upper and $1000 \mathrm{~m}$ at the lower limit. According to Schott et al. (1995) the westward flowing Equatorial Intermediate Current (19Sv) splits west of $35^{\circ} \mathrm{W}$ into a Northern (8 Sv) and a Southern (11 Sv) Equatorial Intermediate Countercurrent (NICC and SICC). These two off-equatorial currents were located at $1.5^{\circ}-3.0^{\circ} \mathrm{N}$ (NICC) and $2.8^{\circ}-1.2^{\circ} \mathrm{S}$ (SICC), respectively. However, since $26.8 \sigma_{\theta}$ lies as high as $200-300 \mathrm{~m}$ depth, these flows may comprise water other than equatorial AAIW. At the equator the strongest westward flow was observed near $600 \mathrm{~m}$, amounting to $u=-20 \mathrm{~cm} \mathrm{~s}^{-1}$ at $35^{\circ} \mathrm{W}$ and $-30 \mathrm{~cm} \mathrm{~s}^{-1}$ at $44^{\circ} \mathrm{W}$. The associated velocity band is truncated at $900 \mathrm{~m}$ at $35^{\circ} \mathrm{W}$ but extends as deep as $1000 \mathrm{~m}$ at $44^{\circ} \mathrm{W}$. 
More recently, Schott et al. (1997) have extended their earlier analysis of the warmwater inflow in equatorial regions from spring 1994. They demonstrate large variations of a factor $\mathcal{O}(3)$ for their "Intermediate Depth Currents" below the $26.8 \sigma_{\theta}$ level and above $1000 \mathrm{~m}$ (their Table 5). Schott et al. (1997) infer a mean westward transport of $22.1 \pm 9.8 \mathrm{~Sv}$ from their four different visits to the $35^{\circ} \mathrm{W}$ site.

In contrast to the studies above, Richardson and Schmitz (1993) observed predominantly eastward equatorial motions at a nominal depth of $800 \mathrm{~m}$ in an early Lagrangian study. In their analysis, they arrive at the conclusion of a broad eastward flow band but they do not rule out a possible westward flow at the AAIW level $(\sim 700 \mathrm{~m})$ as part of the Equatorial Intermediate Current. Since a concurrent velocity profile (Ponte et al., 1990) showed $O\left(8 \mathrm{~cm} \mathrm{~s}^{-1}\right)$ westward flow at $600 \mathrm{~m}$, but eastward flow below (similar to Schott et al.'s (1995) observations at $35^{\circ} \mathrm{W}$ ). Richardson and Schmitz note that the SOFAR floats might be too deep to capture the EIC. The SOFAR floats were ballasted to $800 \mathrm{dbar}$ and did not feature a pressure sensor. It is assumed that they drifted below $800 \mathrm{dbar}$, with a sinking rate of $100 \mathrm{dbar}$ per year due to creep of the pressure housing and thus missed the EIC continuously. In their conclusion, Richardson and Schmitz (1993) remark on the additional possibility of a narrow and variable EIC that might have been positioned between the float trajectories. This difficulty of sampling a narrow EIC has also been noted earlier by Bubnov (1980) and Weisberg (1980) with regard to the data gathered by current meter records.

Within our study, four floats were seeded at and south of the equator at approximately $60 \mathrm{~nm}(111 \mathrm{~km})$ distance. All four floats $(113,114,115$ and 116) drifted between 741 and 808 dbar (see Table 1 and also Fig. 2), with the exception of float 113, which descended to a deeper level (around 850 dbar) between March and April 1995. It remained at this level for the rest of its mission. The monthly displacements (Fig. 3) of float 113 reveal a temporal variability of the EIC. Seeded at the equator, it is instantly trapped by an equatorial wave of $O(500) \mathrm{km}$ wavelength, $100 \mathrm{~km}$ amplitude and of 50 days period. The mean westward float velocity during this period was $\bar{u}=-16.5 \pm 4.4 \mathrm{~cm} \mathrm{~s}^{-1}$. Reaching the South American continental rise in March 1995 , this motion is truncated west of $41^{\circ} \mathrm{W}$ and the float drifts at a more random pattern, eventually drifting back east as far as $38.5^{\circ} \mathrm{W}$ in August 1995 .

We were surprised that float 113 was never caught by the swift North Brazil Current (35 Sv) with its rather small seasonal cycle of $3 \mathrm{~Sv}$ (Schott et al., 1997). Instead it seemed to be trapped near the equator and $42^{\circ} 30^{\prime} \mathrm{W}$ between May and July 1995 . Schott et al. (1997) describe this area of enhanced eddy kinetic energy by an anticyclonic loop of $12 \mathrm{~Sv}$ just north of the equator and by a neighboring cyclonic loop of $19 \mathrm{~Sv}$ at approximately $2^{\circ} \mathrm{N}, 43^{\circ} \mathrm{W}$.

The motion of float 113 and also float 115 suggest an annual cycle of the strength and direction of the EIC (Table 2). Whereas float 113 is captured by the EIC between November 1994 and March 1995, float 115 appears to be trapped by the EIC during the September 1995 and October 1995, just before it bails out and returns to the sea surface. The zonal velocity of float 115 during this period is $\bar{u}=-21.0 \pm 6.5 \mathrm{~cm} \mathrm{~s}^{-1}$ is similar to those observed by float 113 while trapped by the EIC. Quite contrasting, float 114, seeded at $1^{\circ} \mathrm{S}$, crosses the equator three times between March and May 1995 and is not trapped in any zonal flow pattern, be it eastwards or westwards. This 
Table 2

Observations of the EIC ordered by month but regardless of the year. EIC stands for the observations of a westward flow at the equator, whereas EIC, stands for equatorial flow of eastward or zero zonal velocity. Open boxes indicate no observations. Observations by the same instrument but at different occasions are listed in separate lines

\begin{tabular}{|c|c|c|c|c|c|c|c|c|c|c|c|c|}
\hline & Jan. & Feb. & Mar. & Apr. & May. & Jun. & Jul. & Aug. & Sep. & Oct. & Nov. & Dec. \\
\hline \multirow[t]{2}{*}{ RAFOS 113} & EIC & EIC & EIC & ЕIC & ЕIC & & & & & & EIC & EIC \\
\hline & & & EF & & & & & & & & & \\
\hline RAFOS 114 & & & EIC & ЕIC & ЕIC & & & & & & & \\
\hline RAFOS 115 & & & & & Е€ & $\mathrm{Eঙ}$ & & & EIC & EIC & & \\
\hline SOFAR 28 & & EIC & EIC & & & & & & & & & \\
\hline SOFAR 31 & & & & & & & & & & EIC & EIC & \\
\hline & & & & & & & & EIC & EIC & EIC & & \\
\hline Weisberg et al. (1980) & & & & & & & EIC & & & & & \\
\hline Weisberg (1980) & & & & & & & & EIC & EIC & & & \\
\hline Schott et al. (1997) & & & EIC & & & EIC & & & & EIC & EIC & \\
\hline
\end{tabular}

matches to corresponding observations of a stagnant EIC during March-May 1995 (float 113) and May-June 1995 (float 115).

A similar temporal pattern is present in the SOFAR float trajectories of Richardson and Schmitz (1993). Monthly trajectory segments (not shown) indicate a westward flow of SOFAR float 28 in February and March 1989. Between October and November 1989 SOFAR float 31 is trapped in an equatorial westward flow, and again between August 1990 and October 1990. These observations suggest a westward flowing EIC during austral summer and its significant decrease or reversion during austral winter, in agreement with the description of the EIC given by Schott et al. (1997). Reflecting on possible causes for this behavior, they remark that the strength of the EIC is in reciprocal relationship to the strength of the varying equatorial undercurrent. In this context it also seems noteworthy that an annual signal is also visible in sea surface height measurements by TOPEX/POSEIDON (Fu, 1996). Fu notes that the maximum sea level in the equatorial region occurs in September/October, possibly in connection with the maximum strength of the North Equatorial Counter Current.

Before concluding this section, we would like to append that during June 1995, float 113 takes a southeastward course along the western boundary that is remarkably similar to the February 1989 segment of the trajectory of SOFAR float 16 (Richardson and Schmitz, 1993). This flow pattern is consistent with the suggested retroflection of the westward EIC, as depicted in Fig. 8c of Schott et al. (1995), with the retroflection occuring somewhat farther west, near $43^{\circ} \mathrm{W}$.

It seems, that temporal variability (Böning and Schott, 1993; Richardson and Schmitz, 1993), both strong vertical and horizontal shear (Schott et al., 1995) and possible large lateral and vertical mixing (Suga and Talley, 1995); are characteristic for the equatorial current system. Our current interpretation of this data is that the bulk of intermediate water is advected east by the joint SICC and EUC, south of the 

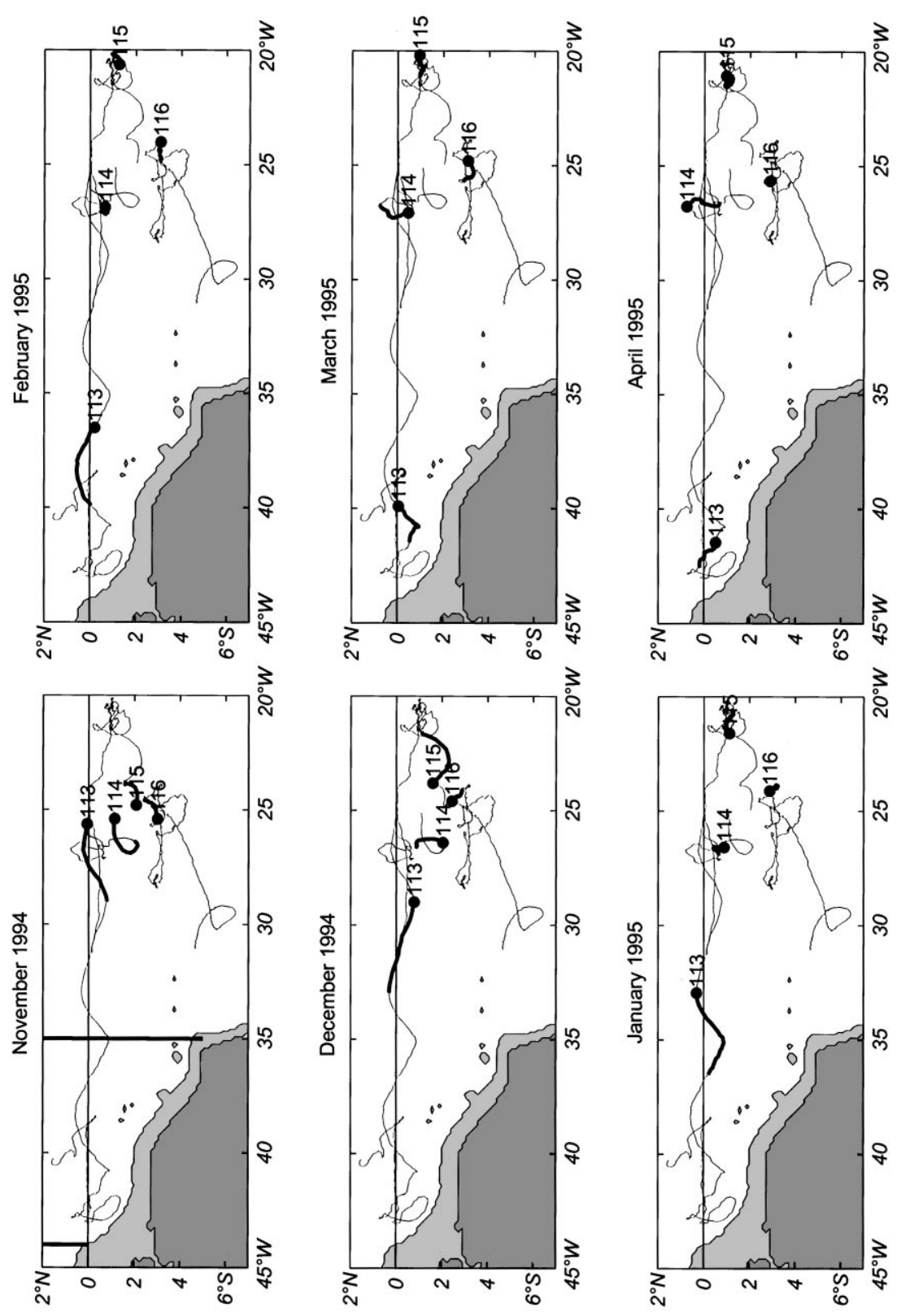

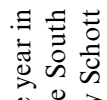

흥흐

정유

छ

品 寻

은 홍

.

氙

ज 항

语

苛鸪

$\Rightarrow \approx 0$

둬류

ลे ํㅡㄹ

㱒

(1)

○氙

$\Xi \Xi$

휴 용

के

苨

वे

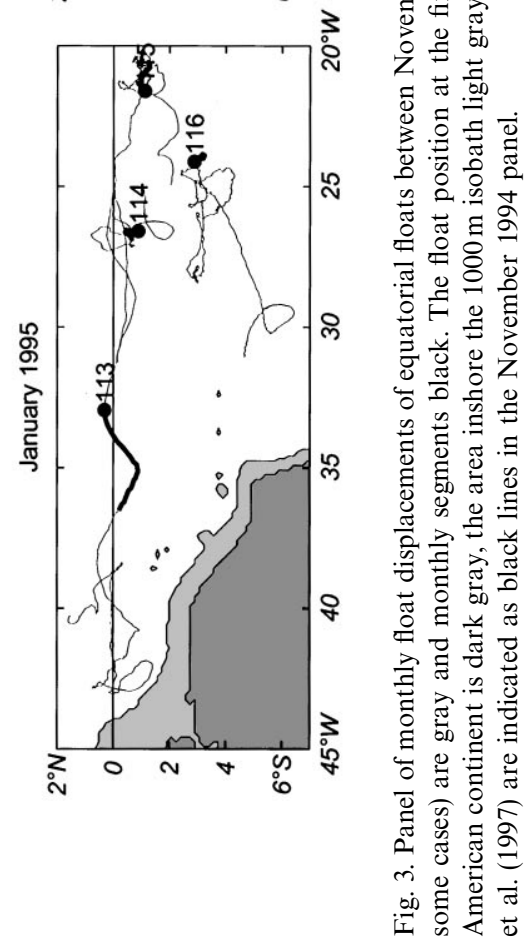



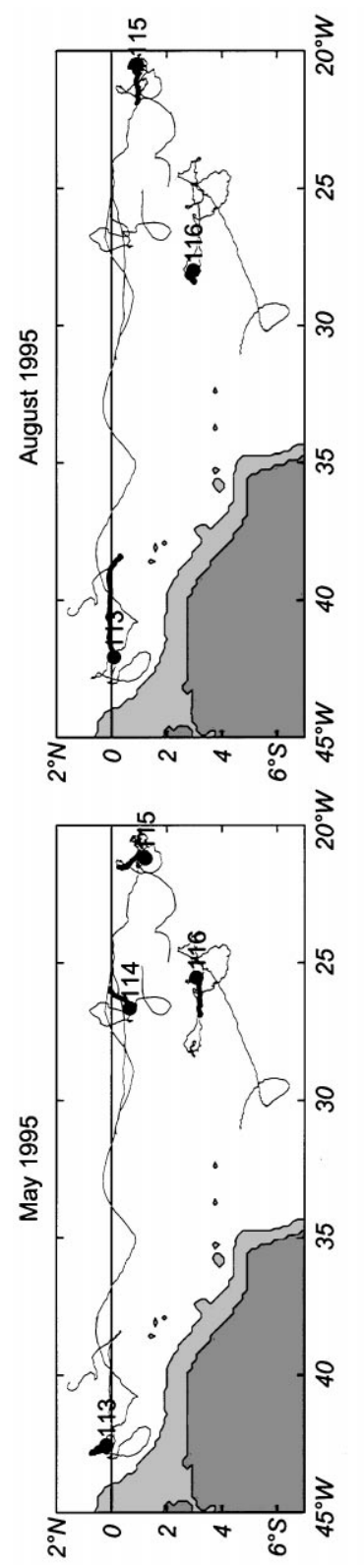
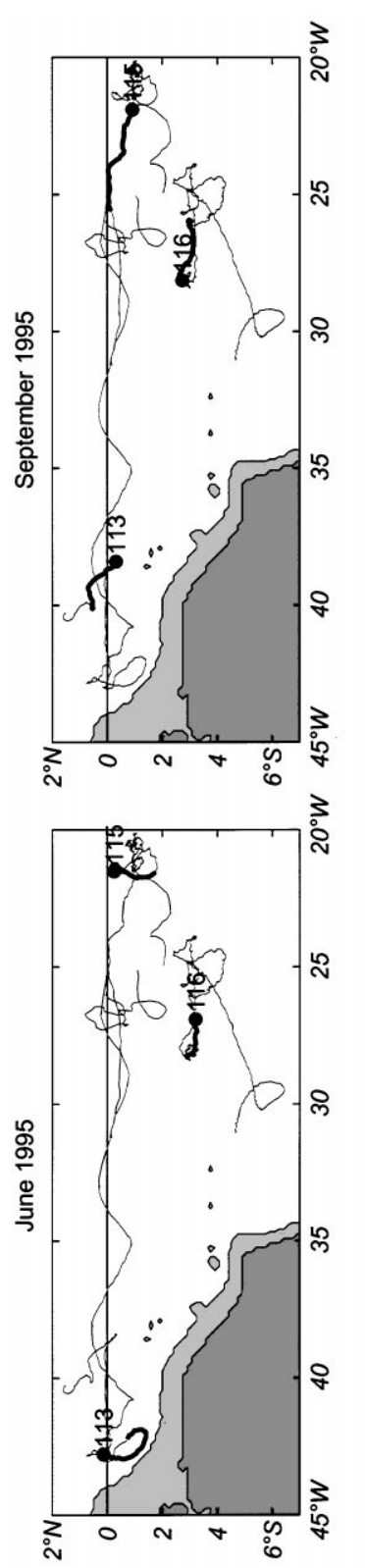
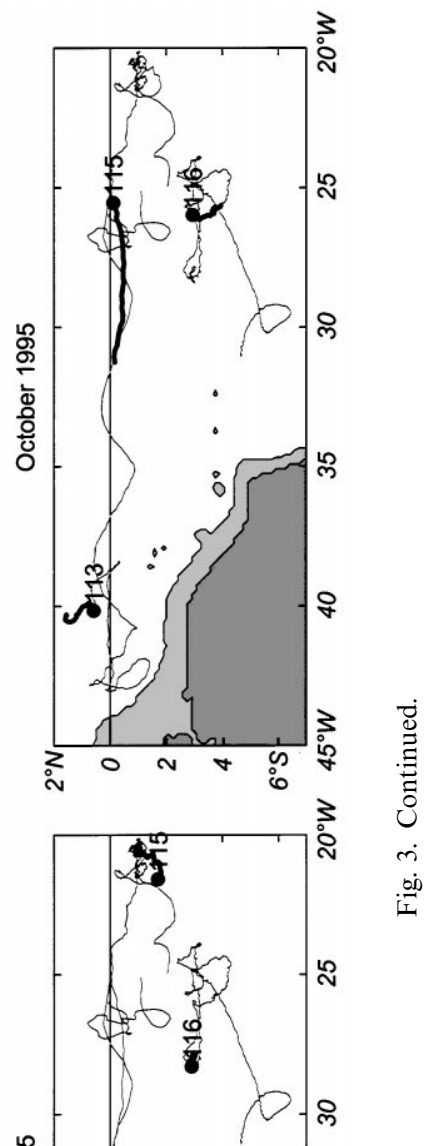
equator (Molinari et al., 1981). This flow, however, is highly variable, and water might move north to the equator along all longitudes. There it can be trapped in the seasonally dependent meandering EIC and transported west at about $20 \mathrm{~cm} \mathrm{~s}^{-1}$. Before it is presumably fed into the IWBC north of the equator it may be recirculated eastward by the NICC or the EIC during one of its eastward phases.

The net effect of the convoluted equatorial flow system is a thorough stirring of the intermediate water along the equator. Whether these processes generate a stable mean flow, is questionable and might be a matter of choosing the "right" time scale. Direct observations of a possible long term mean flow, the existence of which is indeed suggested by the zonally oriented eastward salinity tongue at various isopycnal surfaces (Reid, 1996; Talley, 1996), might only be addressable by spatially and chronologically extensive studies. It is expected that the ongoing and future SAMBA efforts by Ollitrault et al. (1994a) using MARVOR floats will contribute significantly towards the understanding of the intermediate equatorial current system.

\subsection{Eddies at the western boundary}

A considerable part of the poleward IWBC transport north of the equator is via anticyclonic eddies (Richardson and Schmitz, 1993), which translate along the coast at approximately $8 \mathrm{~cm} \mathrm{~s}^{-1}$. A similar anticyclonic eddy was observed south of $5^{\circ} \mathrm{S}$. Here, however, a poleward translation of the eddy implies a reduction of the northward AAIW transport, rather than a contribution to it, as it is the case in the North Atlantic. Near $5^{\circ} \mathrm{S}$ and only $30 \mathrm{~km}$ offshore the $1000 \mathrm{~m}$ isobath, which is believed to be a proxy of the IWBC path, a southward flow associated with the western part of the eddy was observed. Thus, during this occasion, the IWBC width appears to be limited to less than this distance.

The eddy was observed by two floats, 118 (red) and 119 (blue), seeded on 4 November 1994 approximately $111 \mathrm{~km}$ apart (Fig. lb and Fig. 4). During a westward drift which lasts until 28 May 1995, the trajectories converge in January 1995 (Fig. 1b), with float 118 traveling about 10 days behind float 119 for most of the time. The mean westward velocity observed during the period of westward displacement was $-4.8 \mathrm{~cm} \mathrm{~s}^{-1}$. During this drift a prominent anticyclonal feature, centered at $5.6^{\circ} \mathrm{S}$, $31.8^{\circ} \mathrm{W}$ with about 50 days period (Table 3 , column 5 ) is occupied by the two instruments from mid-March 1995 to the beginning of May 1995. But even earlier than this, right after its launch, float 118 exhibits small periodic velocity oscillations of 6-7 days period (not shown), indicating its position close to the center of rotation of an eddy. On 8 January 1995 float 119 performs a small anticyclonic loop (not shown), indicating that this instrument might then have been trapped by the eddy close to its center. Later, during the zonal transit and beyond, between 18 April 1995 and 17 June 1995, float 119 seems to be closer to the eddy center than float 118 .

Upon reaching the western boundary at $5^{\circ} \mathrm{S}$, both floats are deflected to the south. The deflection is coupled to an increase of speed and meridional velocity, which is $-12.7 \mathrm{~cm} \mathrm{~s}^{-1}$ between 28 May 1995 and 27 July 1995, the segment of strongest meridional translation. During this period, the floats drift in close proximity, probably because float 119 had moved away from the presumed eddy center towards float 118 . 

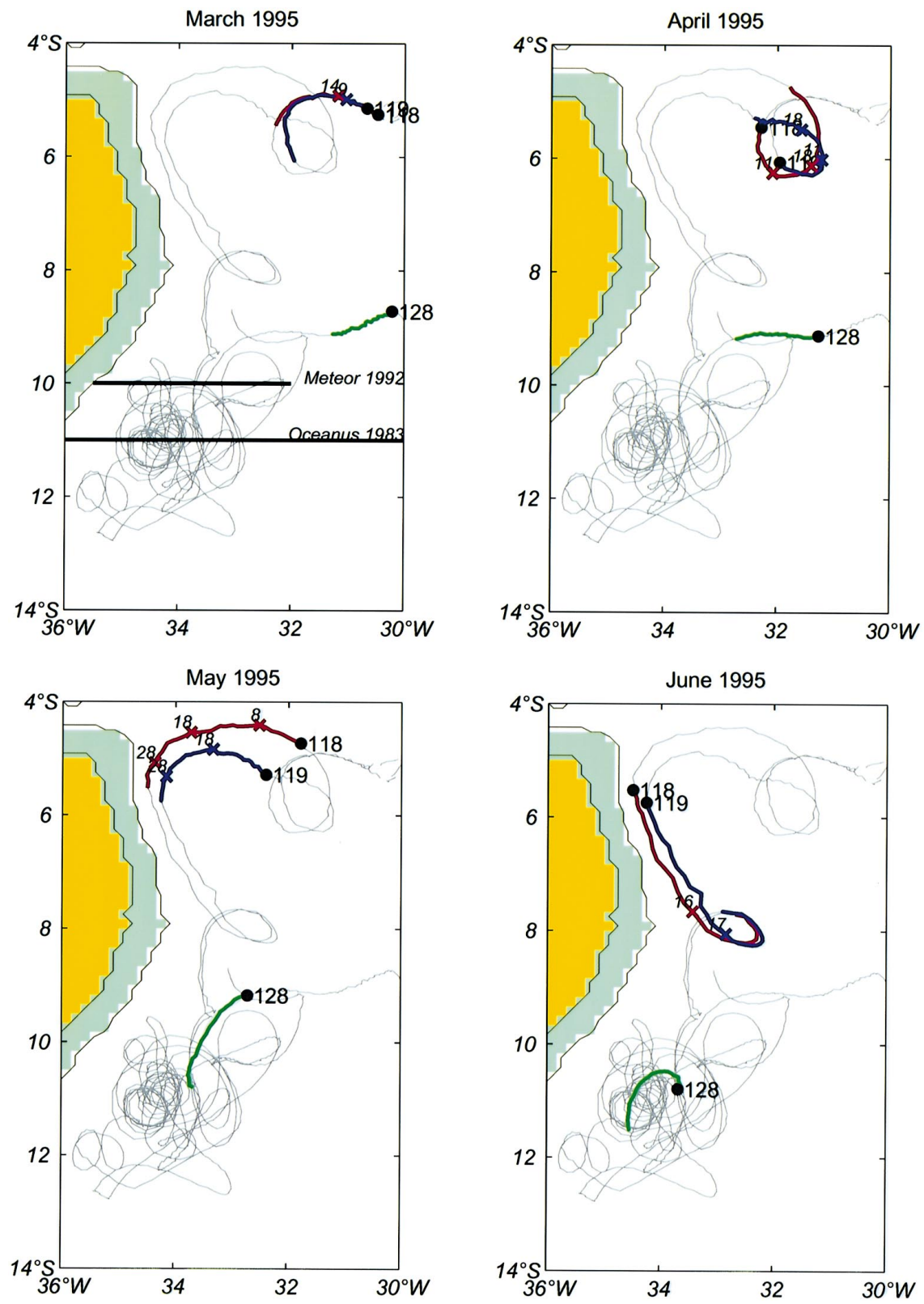

Fig. 4. Monthly displacements of floats 118,119 and 128 between March and October 1995. In gray, the complete trajectory of each float, in red, blue and green monthly segments of floats 118, 119 and 128, respectively. The float position at the first of each month is marked by a black dot and the float number. For convenience, the positions of the zonal sections described by Schott et al. (1997) and Speer et al. (1996) are given in March panel. Crosses with italic numbers indicate the number of days into the respective month. Topography as in Fig. 1b. 

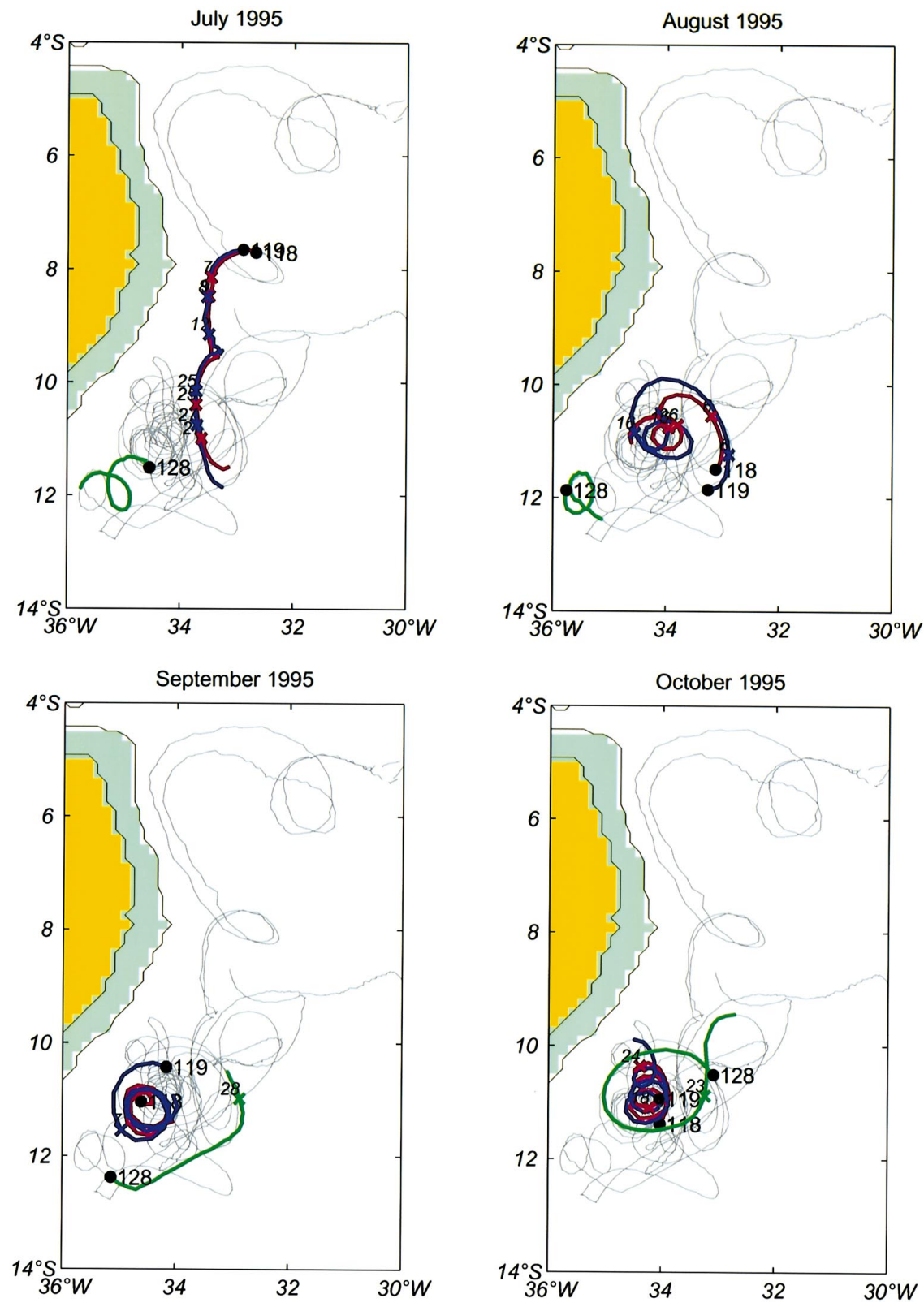

Fig. 4. Continued. 


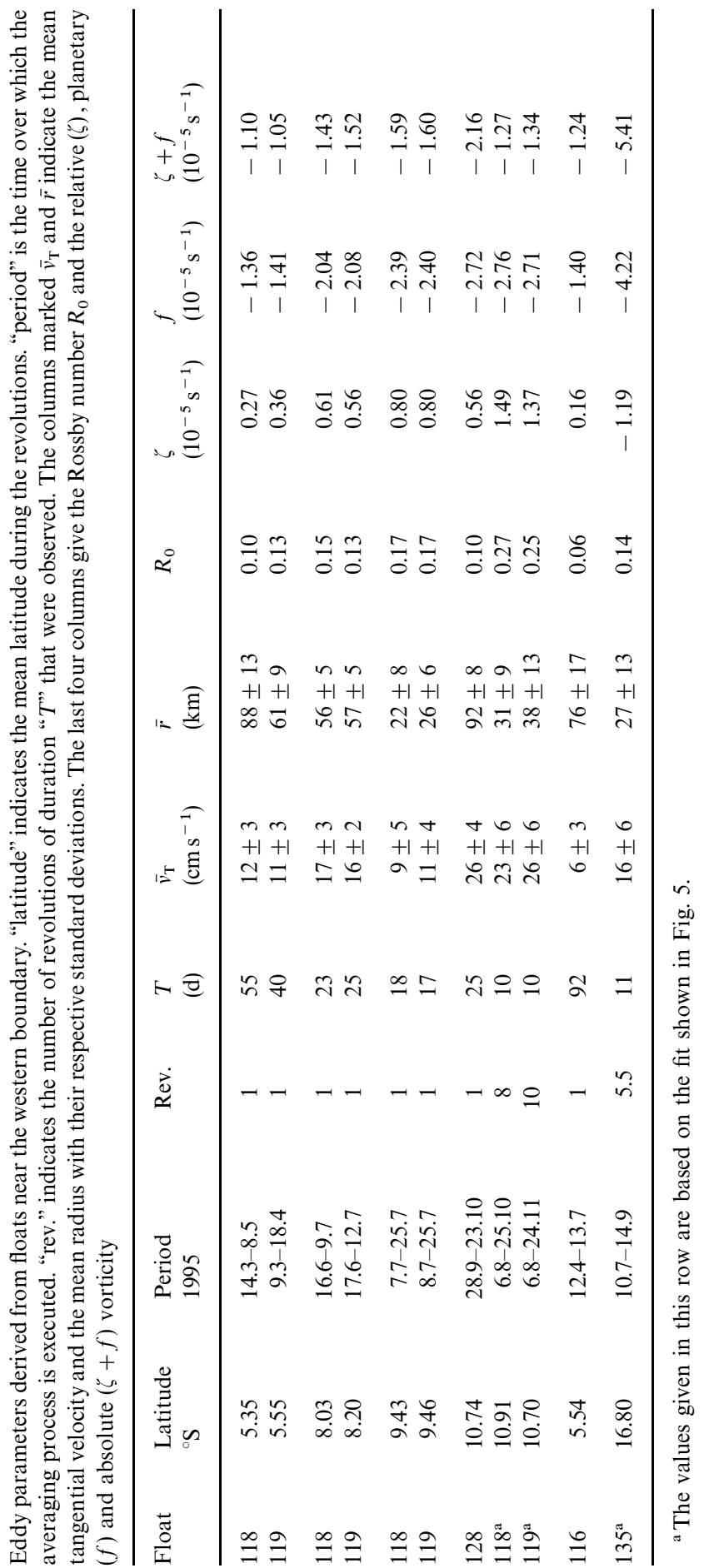


During this transit three anticyclonic loops, spaced by order of $150 \mathrm{~km}$ distance, are observed at $7.9^{\circ} \mathrm{S}, 9.5^{\circ} \mathrm{S}$ and $10.9^{\circ} \mathrm{S}$.

The strong meridional translation ceases in early August 1995. After this the floats circle at about $T=10$ days period (Table 3 , column 5), depicting a quasi-stationary eddy. This latter part of the trajectories has been filtered with a 3rd order Butterworth filter of 10 days cut off frequency. Effectively, this averages the position over one complete revolution, resulting in an approximation of the eddy center motion (Fig. 5a). The residual, that is the trajectory with respect to the eddy center, is plotted in Fig. 5b. Float 118 experiences 8 revolutions before it bails out on schedule of 25 October 1995. Float 119 depicts an additional 2 revolutions, before the anticyclonic motion is lost on 24 November 1995.

The approximate linear relation between speed and radius at radii between 20 and $40 \mathrm{~km}$ (Fig. 5c) indicates that the floats are in the solid body rotational part of an eddy of at least $40 \mathrm{~km}$ radius. An estimate of the Rossby number, $R_{\mathrm{o}}=\bar{v}_{\mathrm{T}} / f \cdot \bar{r}=0.26$, can be made, with the mean tangential speed $\bar{v}_{\mathrm{T}}$, the mean radius $\bar{r}$ and $f$ being the planetary vorticity. These (Table 3, last two rows) and similar values were derived from the linear fit applied to the radius versus speed graph, provided the number of revolutions (column 4) is greater than one. As a direct result of the linear relation between $\bar{v}_{\mathrm{T}}$ and $\bar{r}$, the Rossby number is constant between 20 and $40 \mathrm{~km}$ radius.

In cases where only one revolution (column 4 in Table 3 ) was observed by the float, $\bar{v}_{\mathrm{T}}, \bar{r}$ and $f$ were estimated directly. A residual trajectory was established by integrating the float velocity data over the indicated segment (Table 3, column 3) after subtracting a linear translation (based on the mean segment velocity components). The mean tangential speed $\bar{v}_{\mathrm{T}}$ and the mean radius $\bar{r}$ were calculated from this residual trajectory by averaging the properties over the complete revolution.

The latitudes of all segment data points were averaged to form a mean latitude (Table 3, column 2 ), which was used to calculate the planetary vorticity $f$. Relative vorticity was calculated from the mean tangential speed and the mean radius as $\zeta=2 \bar{v}_{\mathrm{T}} \bar{r}^{-1}$, which corresponds to $\zeta=\partial u / \partial y-\partial v / \partial x$. The segments were chosen to approximate a circle as closely as possible. This, however, could only be met approximately, due to both the eccentricity of the eddy itself and the nonuniform motion of the eddy center during a single revolution.

An upper limit for the solid core radius is given by float 128 . This float approaches the position of the later quasi-stationary eddy at an earlier time and stays primarily to the south of it. On 28 September 1995 it is captured by the eddy at an average radius of $91.8 \mathrm{~km}$. The corresponding Rossby number equals 0.10 (Table 3), which indicates that the float drifts beyond the solid body core with a Rossby number of 0.26 .

Under the assumption of negligible vortex stretching, the absolute vorticity should remain constant for an individual eddy. The last column of Table 3 gives the absolute vorticity $f+\zeta$ for three distinct vortices and for the final quasi-stationary rotations. The gain of negative planetary vorticity, due to the southward propagation of the eddy, is reasonably well compensated by an increase of the magnitude of the relative vorticity. The values given for the three single revolutions were stable to order of $\pm 0.2 \times 10^{-5} \mathrm{~s}^{-1}$ when varying the start end points of each segment (a procedure taken routinely to select the most circular segment). During the eddy's vicious 

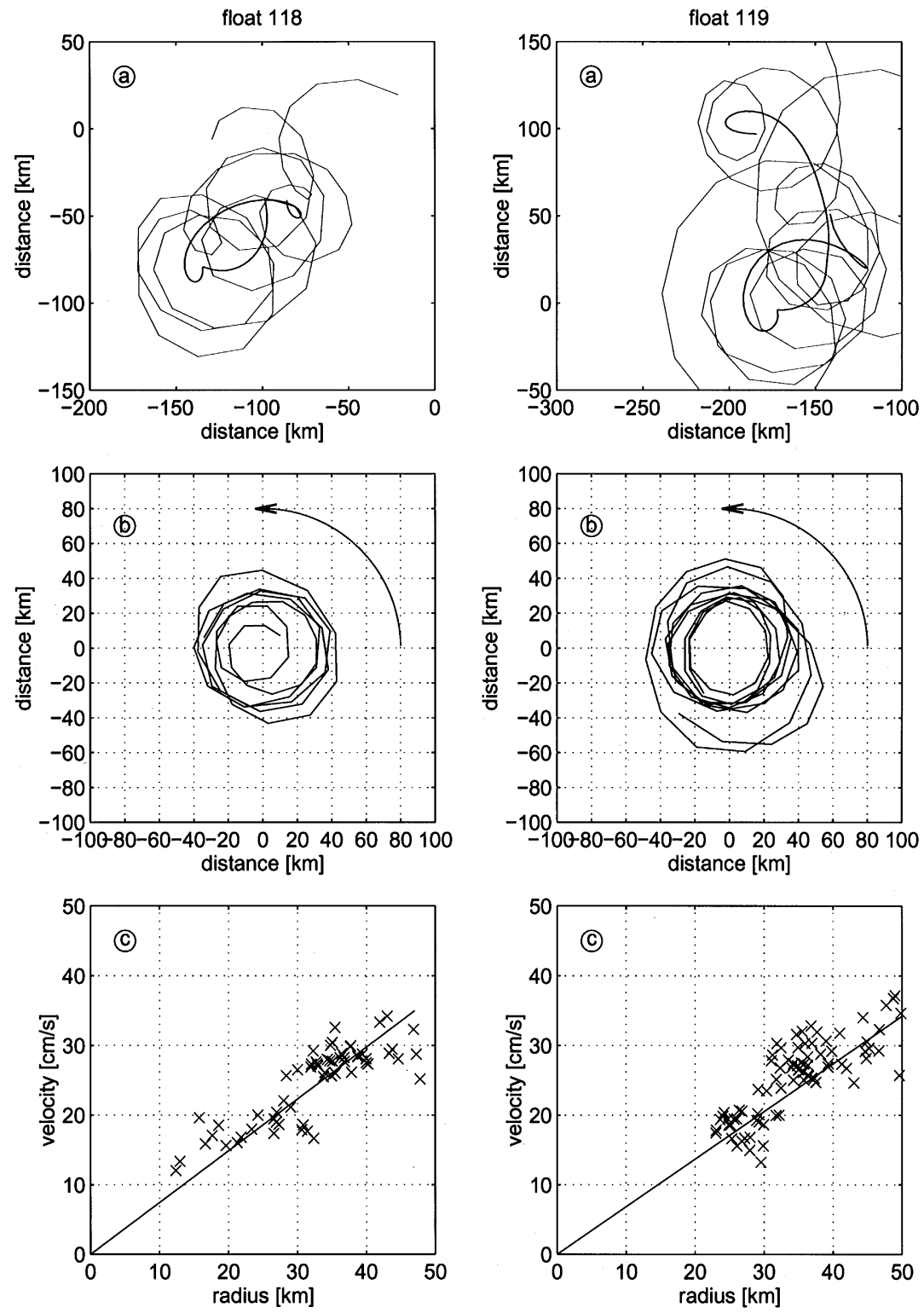

Fig. 5. (a) Raw (gray) and filtered (black) trajectories of floats 118 (left) and 119 (right). (b) Trajectory of RAFOS float 118 (left) and 119 (right) relative to eddy center. (c) scatter plot of velocity versus radius for floats 118 (left) and 119 (right). The solid line represents a linear fit of the data, with a forced fix at the origin.

southward translation, however, considerable uncertainties are introduced through a varying planetary vorticity along the trajectory. Therefore the most reliable estimates are for the first revolution, where the averaging process runs over a long period 
with little meridional advection, and for the quasi-stationary final part, where the linear fit of Fig. 5 was used to obtain the kinematic parameters. Hence, we suggest to assume values between -1.1 and $-1.3 \times 10^{-5} \mathrm{~s}^{-1}$ as the most likely estimates of the eddy's absolute vorticity. The close resemblance of initial and final values indicates that this eddy is an only feature, with the observed spin up due to the $\beta$-effect. The notion that the floats are trapped continuously within an anticyclonic eddy is also a good explanation for the coherent motion of these floats for a one year period.

It is interesting to reflect on the significance of this kinematic pattern. Does it have to be judged as a singular event or is it repetitive? Evidence for a possible repetition was captured by float 116 (Fig. 1) during the later part of its mission between 12 April 1996 and 13 July 1996 . Float 116 originated at $3^{\circ} \mathrm{S}$ and drifted slowly to the southwest, before it exhibits an anticyclonic loop. This feature is of similar extent $(\bar{r}=76.4 \mathrm{~km})$ and position $\left(5.8^{\circ} \mathrm{S} 29.6^{\circ} \mathrm{W}\right)$ as the eddy captured by floats 118 and 119 during their first large revolution about one year earlier (March-May 1995). The period of this new anticyclone is estimated to 92 days (Table 3), and the absolute vorticity $-1.24 \times 10^{-5} \mathrm{~s}^{-1}$ is close to that estimated for the earlier eddy. Similar to float 118 and 119, float 116 continues to the west before it stops on 21 July 1996.

Other evidence for an offshore counterflow can be found in the literature. In a $10^{\circ} \mathrm{S}$ velocity section, Schott et al. (1995) observe a southward flow of order $10 \mathrm{~cm} \mathrm{~s}^{-1}$ cast of $34^{\circ} \mathrm{W}$ (their Fig. 7). The flow directions at the stations farther west, however, indicate a cyclonic feature, circulating water with southern water mass properties. In their northern section, at about $5^{\circ} \mathrm{S}$, a southward velocity core at $700 \mathrm{~m}$ of up to $10 \mathrm{~cm} \mathrm{~s}^{-1}$ is observed near $34.5^{\circ} \mathrm{W}$, east of the strong northward IWBC signal.

In a hydrographic section at $11^{\circ} \mathrm{S}$, occupied in 1983 by RV OCEANUS in March-April 1983, a conspicuous spike occurs in the AAIW volume transport (Speer et al., 1996, their Fig. 6) indicative of a southward counterflow to the northward IWBC. At intermediate depth the velocity section (Fig. 6) indicates a southward flow of more than $10 \mathrm{~cm} \mathrm{~s}^{-1}$ centered around $35^{\circ} \mathrm{W}$ with northward flow both east and west of it. The southward flow is more pronounced at mid depth than at near-surface and appears to be connected to the southward flowing core of upper North Atlantic Deep Water, centered at $2000 \mathrm{~m}$ depth. Even though a clear eddy structure is not apparent, the southward flow suggests that the counterflow observed by our floats is not to be judged as a rare event.

To our knowledge this is the first time that the southward migration of an eddy at intermediate depth has been directly observed in the tropical South Atlantic. Its southward movement is against the general direction of the northward AAIW spreading but is in agreement with Nof's analytical finding of eddy migration along western boundaries (Nof, 1983). Schmid et al. (1995) documented the equatorward drift of the cyclonic Victoria eddy along the Brazilian coast line, interacting with the local topography. Here we deal with the opposite case of the poleward migration of an anticyclone. Its origin is in the tropical waters, maybe as a deep expression of an eddy in the South Equatorial Current. It is questionable whether the observed eddy is related to an Agulhas ring, since the latter have been observed only as far north as around about $30^{\circ} \mathrm{S}$ (Lutjeharms, 1996). In addition, the accompanying CTD cast (not shown) during launch of float 118 does not give any indication of saltier Indian Ocean 


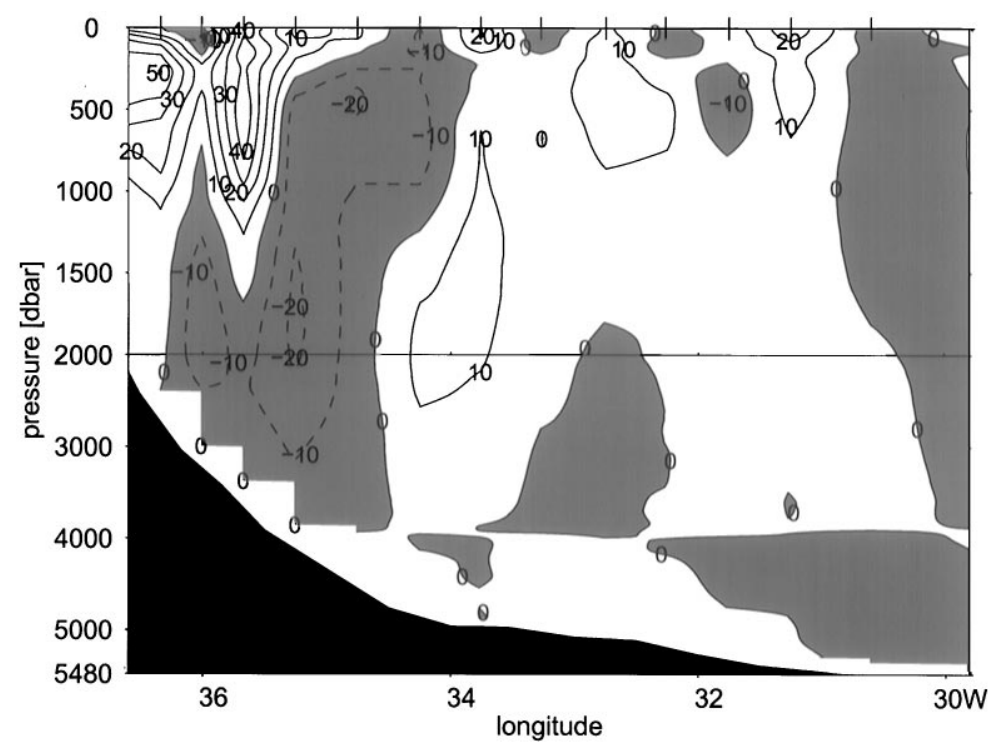

Fig. 6. Geostrophic velocities of RV OCEANUS section near $11^{\circ} 25^{\prime}$ S (Fig. 4). Southward currents are shown in gray. Where possible, the interface between the North Atlantic Deep Water and the Antarctic Bottom Water at $\sigma_{3}=41.55 \mathrm{~kg} \mathrm{~m}^{-3}$ was chosen as reference level. Elsewhere the deepest station pair was chosen.

water at intermediate depth. The chronologically unrelated OCEANUS hydrographic section at $11^{\circ} \mathrm{S}$, however, depicts a lens centered at the depth of the upper North Atlantic Deep Water, with the dynamic signal reaching into the waters at intermediate depth.

Farther south, an additional eddy was observed near the western boundary (Fig. 7). Near $17^{\circ} \mathrm{S}$, a cyclonic eddy trapped float 135 after it was entrained into the IWBC near $19^{\circ} \mathrm{S}$ and advected north at around $15 \mathrm{~cm} \mathrm{~s}^{-1}$. The eddy was locked in a canyon with a facing seamount at its mouth. The float takes 5.5 revolutions of 7-14 days period before it is expelled to the east. Then the float resumes a cyclonic motion of 25 days period near $15.6^{\circ} \mathrm{S} 35.7^{\circ} \mathrm{W}$. The analysis, based on the assumption of $T=11$ days (Table 3), gives a quasi-linear relation between distance and velocity (resulting in a fitted angular frequency $\left.\omega=6 \times 10^{-6} \mathrm{~s}^{-1}\right)$. The average observed radius is $26.7 \pm 12.6 \mathrm{~km}$ with a mean tangential velocity of $15.9 \mathrm{~cm} \mathrm{~s}^{-1}$. For this feature, the Rossby number was calculated as 0.14 and the absolute vorticity as $-5.41 \times 10^{-5} \mathrm{~s}^{-1}$. This trajectory exemplifies for the direct exchange of the water of the IWBC and of the interior ocean, which at last generates the northward salinity tongue which is wider than the IWBC itself.

\subsection{Eddy diffusion in the tropical gyre}

Recent discussions of the tropical gyre reveal considerable uncertainty regarding its overall structure. The multitracer study by Larqué et al. (1997) proposes a single 

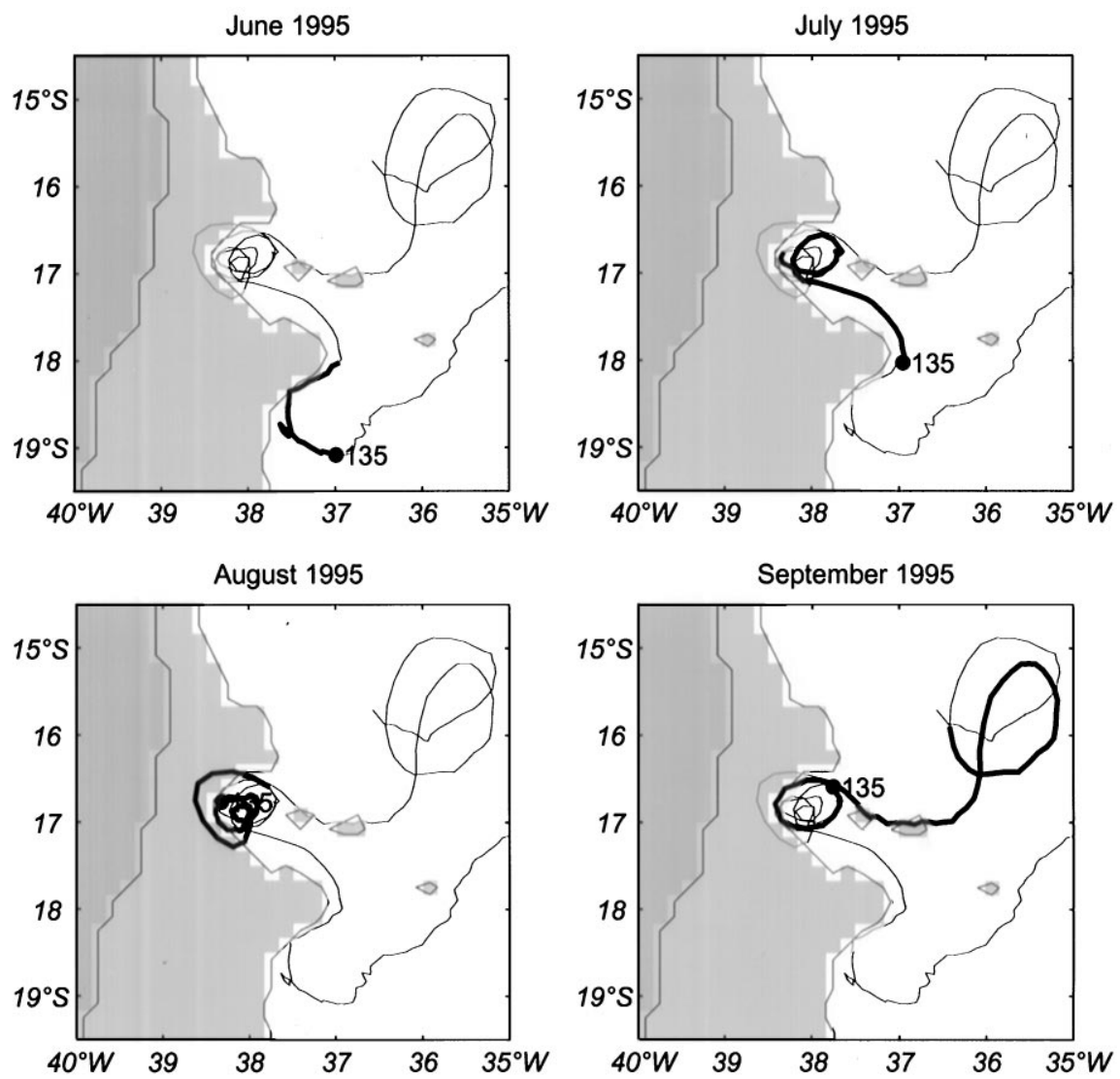

Fig. 7. Monthly displacements of float 135 between June and September 1995. In gray, the complete trajectory and monthly segments in black. The float position at the first of each month is marked by a black dot and the float number. Topography as in Fig. 3.

cyclonic gyre, whereas an earlier study by Suga et al. (1995) suggests a triple cyclonicanticyclonic-cyclonic gyre structure. Nevertheless, these and other studies (Talley, 1996; Tsuchiya et al., 1994) agree in associating the southernmost extend of the tropical gyre with a front observed in the oxygen fields of meridional sections near $25^{\circ} \mathrm{S}$.

The oxygen content north of the front is below $4.0 \mathrm{mll}^{-1}$. South of it, within the subtropical gyre, concentrations above $5.0 \mathrm{ml}^{-1}$ are found. Most outstanding is a steep rise of the $4.5 \mathrm{ml}^{-1}$ oxygen isoline near $25^{\circ} \mathrm{S}$ at $25^{\circ} \mathrm{W}$ (Tsuchiya et al., 1994) and near $28^{\circ} \mathrm{S}$ along the Greenwich meridian (Suga and Talley, 1995) (corresponding to their front "F1"). This front is not associated with a velocity maximum, since it is not reflected in the isopycnal field, but it separates floats of distinctly different kinematic behavior, north and south of the front. More precisely, the division follows the $4.5 \mathrm{mll}^{-1}$ oxygen isoline on the $27.3 \sigma_{\theta}$ isopycnal (Suga and Talley, 1995, their Fig. 3). 
Two groups of floats $(37,43,47,51,57,58$ and 124, 128, 129, 130, 131, 132, 133) were launched within the tropical gyre, that is, north of the oxygen front, offshore the western boundary regime and south of $5^{\circ} \mathrm{S}$ (Fig. 1b, red float labels). They remained within the tropical gyre for their whole mission, showing comparably little displacement, which enables us to interpret their ensemble means as representative for this ocean region. The ensemble mean zonal (westward) advection observed is $\bar{u}=-0.21 \mathrm{~cm} \mathrm{~s}^{-1}$, whereas the meridional (northward) advection is smaller by a factor of $3\left(\bar{v}=0.07 \mathrm{~cm} \mathrm{~s}^{-1}\right)$. In comparison with the zonal mean flow observed by floats in the subtropical gyre return current (see below) to the south, the zonal velocity component in the tropical gyre is reduced by more than a factor of 10 .

The diffusion coefficients $K_{i i}=I_{i i} \cdot \bar{u}_{i}^{\circ 2}$ within the tropical gyre are estimated as $1.48 \times 10^{7} \mathrm{~cm}^{2} \mathrm{~s}^{-1}$ (zonal, $i=$ "u") and $0.61 \times 10^{7} \mathrm{~cm}^{2} \mathrm{~s}^{-1}$ (meridional, $i=$ "v"). These estimates are based on the calculation of the zonal and meridional autocorrelation functions

$$
R_{i j}(\tau)=\frac{1}{\overline{u_{i}^{\prime 2}}}\left\langle\frac{1}{\mathrm{~T}} \int_{0}^{\infty} u_{i}^{\prime}(t) \cdot u_{j}^{\prime}(t+\tau) \mathrm{d} t\right\rangle
$$

following closely the description given by Figueroa and Olson (1989). Integrating the autocorrelation function yields estimates of the Lagrangian integral time scale $I_{i i}(T)=\int_{0}^{T} R_{i i}(\tau) \mathrm{d} \tau$ (Fig. 8a) as a function of the upper limit $T$ of the integral. The zonal component (solid line) peaks at $T=19$ days and reaches a quasi-steady value after 150 days. The meridional component levels earlier, around 110 days, after having reached a peak value at $T=10$ days. Following Figueroa and Olson's (1989) suggestion to choose the integral time scale estimate at mid-time $(T=150$ days $)$, we assume the
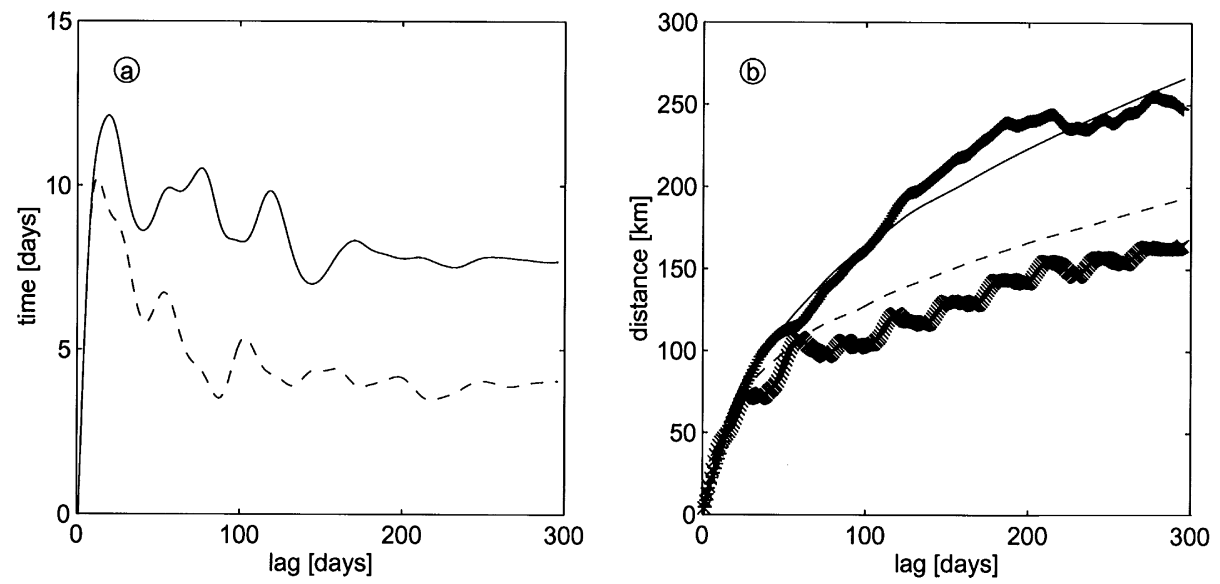

Fig. 8. (a) Estimates of Lagrangian integral time scale $l_{i i}$ as a function of time lag, ensemble averaged over RAFOS floats 124, 128, 129, 130, 131, 132, 133, 37, 43, 47, 51, 57 and 58 (Fig. 1b, red float numbers). (b) Integrated functions of diffusivity $2 \int_{0}^{1} K_{i i}(t) \mathrm{d} t$ and dispersion time series $\left\langle X_{i i}^{\prime 2}(t)\right\rangle$ ensemble averaged over the above floats. The zonal and meridional components are indicated by solid and dashed lines (for the diffusivity integral) and plusses and crosses (for the dispersion function), respectively. 
Lagrangian integral time scale as 8 days (zonal) and 4 days (meridional). Multiplying these values with the respective velocity variance $\overline{u_{i}^{\prime 2}}$ yields the diffusion coefficients as given above.

These estimated integral time scales lie at the low end of the range of Lagrangian integral time scales found at intermediate depth (Böning, 1988) and are similar to those found at sea surface ( 8 (zonal) and 3 (meridional) days) in the closest box of Figueroa and Olson's (1989) study of drifting FGGE-buoy data. The eddy diffusivity of the tropical gyre shows the anisotropy commonly found, with the zonal component being twice as large as the meridional. The values of eddy kinetic energy density (19.0 $\mathrm{cm}^{2} \mathrm{~s}^{-2}$ (zonal) and $17.8 \mathrm{~cm}^{2} \mathrm{~s}^{-2}$ (meridional)) are again at the low end of the range observed at mid-depth (Böning, 1988) and by an order of magnitude smaller than those found at sea-surface (Figueroa and Olson, 1989).

The validity of diffusion estimates based on the autocorrelation functions is subject to the necessity of statistical stationarity and homogeneity. To test the validity of these assumptions, both sides of Taylor's theorem (Taylor, 1921) can be calculated independently (Freeland et al., 1975) and compared. The specific calculation chosen here again follows the description given in Figueroa and Olson (1989), with the exception of subtracting an ensemble mean velocity before integrating the velocity data rather than the individual floats' mean velocity.

The comparison (Fig. 8b) shows reasonable agreement. The zonal component (solid line for the integrated autocorrelation function and pluses for the directly calculated displacement) are in close proximity in the linear regime until day 40 . The transition to the regime following a $t^{1 / 2}$-law is reasonable, but beyond day 100 strong local deviations are observed. Most likely this is based on sampling errors due to the limited amount of data. The meridional component (dashed line for the integrated autocorrelation function and crosses for the directly calculated displacement) agrees well for the first 30 days. Thereafter, the displacement follows the radical shape of the dashed line, but gives smaller values throughout.

In summary, our findings describe the south-western part of the tropical gyre as an area of low advective and eddy diffusive activity, suggesting the stagnation of the tropical gyre across a wide range of kinematic scales. This finding supports the notion of Tally (1996) (p. 229) that the "low oxygen content of the tropics is due to long residence time rather than especially high consumption". Exchanges with surrounding regimes seem to occur mostly at the western boundary through entrainment and detrainment IWBC water. Our floats can neither confirm a triple (Suga and Talley, 1995) or single (Larqué et al., 1997) advective pattern of the tropical gyre, since it seems without advective structure altogether. It should be noted, however, that the floats were drifting at the southern and western perimeter of the tropical gyre, and thus might not capture a possible advective pattern farther to the north and east.

\subsection{Advection in the subtropical gyre}

It is generally agreed that at least most of the northward flowing AAIW is carried around the subtropical gyre on its journey from its formation sites in the South to the 


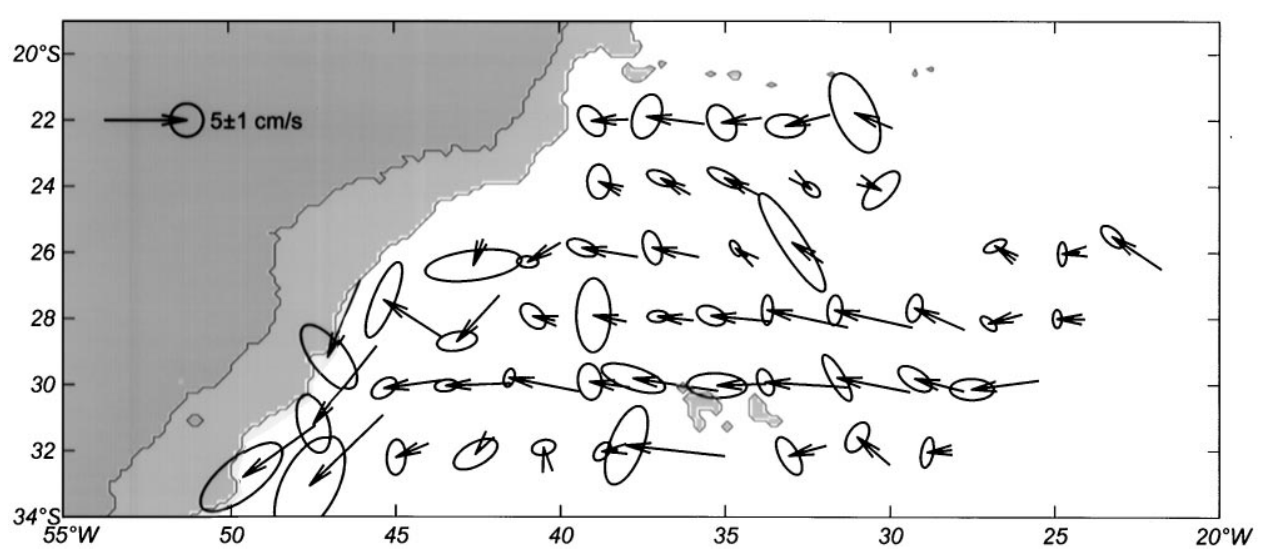

Fig. 9. Mean flow and error ellipses of the subtropical gyre return flow. Only data between 650 and 1050 dbar were accepted for statistical analysis.

equatorial regions (Boebel et al., 1997a; Piola and Gordon, 1989; Reid, 1994; Talley, 1996). Based on a much smaller data set, Boebel et al. (1997b) observe the center of the westward subtropical gyre return flow near $30^{\circ} \mathrm{S}$ to be of remarkable uniformity. The float trajectories reveal a negligible influence of the Rio Grande Rise, protruding up to less than $1000 \mathrm{~m}$ depth. East of $40^{\circ} \mathrm{W}$, the flow is dominantly zonal (Fig. 9). Farther west, the influence of the continental shelf deflects the current to the southwest. Not explicitly captured by this float data set, but clearly observed by earlier moored current meter observations (Boebel et al., 1997b), is the formation of the IWBC near $28^{\circ} \mathrm{S}$, which follows the western boundary across the Vitória-Trindade Ridge and farther north (Boebel et al., 1997a).

However, within the area between Vitória-Trindade Ridge $\left(21^{\circ} \mathrm{S}\right)$ and little south of the Rio Grande Rise at $33^{\circ} \mathrm{S}$, sufficient data are available to calculate maps of second-order statistical properties such as error estimates and eddy kinetic energy. For this purpose, the float velocity data were binned into boxes of $2^{\circ}$ latitude by $2^{\circ}$ longitude (which resulted in a maximum of 537 daily float observations within one box). Estimates are made independently for each box, with the exception of the zonal (21 days) and meridional (11 days) Lagrangian integral times scales, which are estimated according to the method employed in the previous chapter. Mean velocities and error estimates were calculated according to description given by Boebel et al. (1997b), however with 90\% error ellipses and independent zonal and meridional Lagrangian integral time scales used in this study.

The current's variability, as expressed in the ratio of mean (mke) to eddy (eke) kinetic energy density (Fig. 10), is remarkably high. The mke is of the same order as the eke, about $1 \mathrm{~J} \mathrm{~m}^{-3}$. North of the current, between $27^{\circ} \mathrm{S}$ and the Vitória-Trindade Ridge, the eke dominates over the mke, which might be due to the influence of the ridge and the IWBC struggling to find a passage to the north across the VitoriaTrindade Ridge. In the wake of the Rio Grand Rise, an eddy structure (Table 4) has 


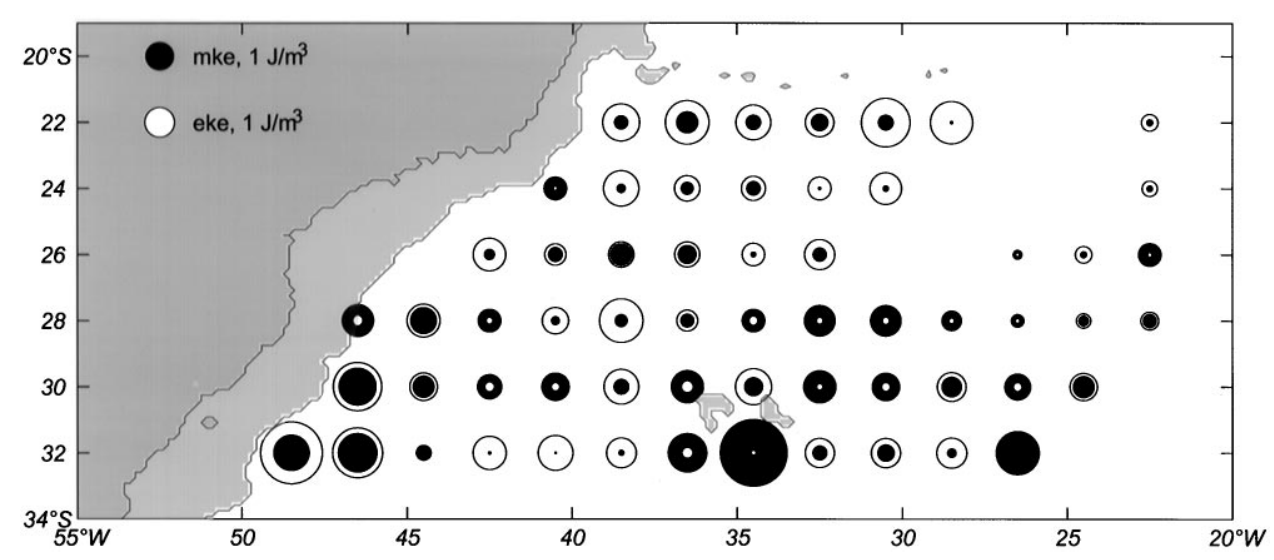

Fig. 10. Mean kinetic energy density ( $m k e$, full circles) and eddy kinetic energy density ( $e k e$, open circles) of the subtropical gyre return flow. The energy density is proportional of the area of the circle.

Table 4

Eddy parameters of anticyclonic eddy observed by float 97. See Table 3 for an explanation of the abbreviations

\begin{tabular}{lllllllllll}
\hline Float & $\begin{array}{l}\text { Latitude } \\
\left({ }^{\circ} \mathrm{S}\right)\end{array}$ & $\begin{array}{l}\text { Period } \\
1995\end{array}$ & Rev. & $\begin{array}{l}T \\
(\mathrm{~d})\end{array}$ & $\begin{array}{l}\bar{v}_{\mathrm{T}} \\
\left(\mathrm{cm} \mathrm{s}^{-1}\right)\end{array}$ & $\begin{array}{l}\bar{r} \\
(\mathrm{~km})\end{array}$ & $R_{0}$ & $\begin{array}{l}\zeta \\
\left(10^{-5} \mathrm{~s}^{-1}\right)\end{array}$ & $\begin{array}{l}f \\
\left(10^{-5} \mathrm{~s}^{-1}\right)\end{array}$ & $\begin{array}{l}\zeta+f \\
\left(10^{-5} \mathrm{~s}^{-1}\right)\end{array}$ \\
\hline 97 & 29.00 & $19.5-14.7$ & 5 & 10 & $10 \pm 3$ & $16 \pm 5$ & 0.09 & 1.32 & -7.08 & -5.75 \\
\hline
\end{tabular}

been captured only once by one float (float 97, Fig. 1b), showing 5 revolutions between 19 May 1997 and 14 July 1995 while advecting west at $-6.0 \mathrm{~cm} \mathrm{~s}^{-1}$.

The flow scheme described here is in general agreement with recent geostrophic estimates by Reid (1996) and Talley (1996). Some differences are found in details, like the position of the axis of the subtropical gyre, which Reid puts at $30^{\circ} \mathrm{S}$ but we find somewhat farther south at $35^{\circ} \mathrm{S}$. Further, in this study, the current seems to have a predominantly zonal orientation and is more confined in its lateral extension, whereas the geostrophic estimates suggest a wider and more northwestward oriented flow, probably due to the large spacing between sections.

Recent modeling efforts seem to be quite appropriate in describing the subtropical gyre return flow, since they resemble our results both in magnitude and locations (England and Garcon, 1994). Barnier et al. (1996) produce a preferably zonal return flow between $30^{\circ} \mathrm{S}$ and $24^{\circ} \mathrm{S}$ of 2 to $3 \mathrm{~cm} \mathrm{~s}^{-1}$ strength along with the bifurcation at the continental shelf. Their gyre axis is located in the west along $35^{\circ} \mathrm{S}$, and at somewhat higher latitudes farther east. The return flow derives the bulk of its waters from the South Atlantic Current at locations east of the Mid-Atlantic Ridge. 


\subsection{Meanders of the South Atlantic Current}

The South Atlantic Current (Stramma and Peterson, 1990), is thought to be the southern limb of the subtropical gyre, spanning the width of the South Atlantic at about $40^{\circ} \mathrm{S}$. It is usually associated with the Subtropical Front (STF, following the terminology used by Stramma and Peterson (1990)), featuring strong gradients in salinity $(\Delta S \geqslant 0.5)$ and temperature $\left(\Delta T \geqslant 4^{\circ} \mathrm{C}\right)$. The $\mathrm{STF}$ is organized in a complex process, generated by the collision of the Brazil and Falkland Currents, which carry water of subtropical (from the Santos Bifurcation) and subantarctic origin, respectively. East of $42^{\circ} \mathrm{W}$, however, the STF appears to have evolved into a distinct front. In the following we avoid to distinguish between the Brazil Current Front and the Subtropical Front, because the relevance of the former within the deeper ocean is unclear.

In general, the floats presented in Fig. 11 drift eastward across the Argentine Basin. Fig. 11 emphasizes high velocity data, with daily float positions in excess of a speed $|\mathbf{v}|>15 \mathrm{~cm} \mathrm{~s}^{-1}$ marked by red dots on top of the underlying gray trajectories. Hereinafter these high speed data are used as a proxy for the South Atlantic Current. At $40^{\circ} \mathrm{W}$, the SAC center appears to be situated at $39^{\circ} \mathrm{S}$ and reaches somewhat higher latitudes farther east. There, the surface expression of the STF is generally assumed farther north (Stramma and Peterson, 1990), but occasionally the STF front has been observed as far south as $43^{\circ} \mathrm{S}$, as indicated by the black "error bars" (Fig. 11) that mark historic positions of the STF (Stramma and Peterson, 1990). Deacon (1937) ascribed these southward protrusions of the STF to shallow patches of subtropical water on top of subantarctic water. This, however, would imply that the deep expression of the STF should be found at lower latitudes. In contrast, our data suggest that the deep expression of the STF also may be found at these southern latitudes.

Deacon (1937) described the variability of the location of the STF to be as high as $6^{\circ}$ in latitude, an observation also supported by Stramma and Peterson (1990). The multitracer study of Largué et al. (1997) gives indications for significant excursion of the STF near $40^{\circ} \mathrm{S}$ at $44-45^{\circ} \mathrm{W}$ and $38^{\circ} \mathrm{W}$. It appears that within the given uncertainty of the width of the observed flow band, the intermediate component of the SAC and the STF coincide. At intermediate depth, the floats show several strong meanders of up to $500 \mathrm{~km}$ amplitude, in agreement with the $6^{\circ}$ displacement of the STF observed by Deacon (1937). These meanders generate a convoluted flow pattern that sometimes folds back on itself.

Geostrophic calculations of the westward surface velocities associated with the SAC range between 10 and $30 \mathrm{~cm} \mathrm{~s}^{-1}$ (Stramma and Peterson, 1990), with lower values at intermediate depth. Reid et al. (1977) report AAIW speeds of up to $10 \mathrm{~cm} \mathrm{~s}^{-1}$ at $35^{\circ} \mathrm{S}$ across a south-westward oriented section. These values have been exceeded by the daily velocities observed by the floats. Speeds range as high as $60 \mathrm{~cm} \mathrm{~s}^{-1}$ with an average of $13.1 \mathrm{~cm} \mathrm{~s}^{-1}$. The box average westward velocity component is of order $5 \mathrm{~cm} \mathrm{~s}^{-1}$. For a substantial number of data points $(30 \%)$ the flow within the current is in excess of $15 \mathrm{~cm} \mathrm{~s}^{-1}$. In comparison with the subtropical gyre return flow, we observe only slightly higher mean zonal velocity components $\left(5 \mathrm{~cm} \mathrm{~s}^{-1}\right.$ versus $3 \mathrm{~cm} \mathrm{~s}^{-1}$ ), but significantly stronger meanders and exchange between the SAC and the stagnant region of the subtropical gyre center to the north. 


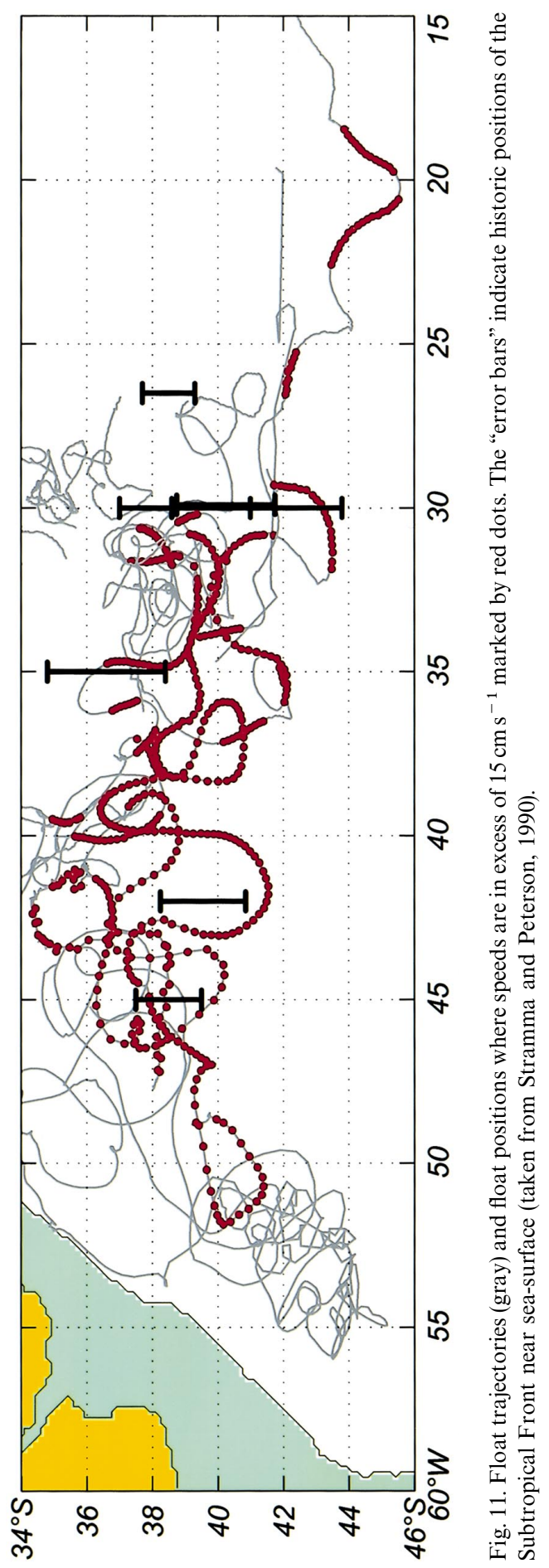


Stramma and Peterson (1990) describe the surface expression of the SAC as being distinct from the ACC. At intermediate depth and downstream of the Confluence Zone, a number of ALACE floats seeded in the Drake Passage (Davis et al., 1996) eventually drift towards the positions occupied by our RAFOS floats that were seeded in the subtropics. The easternmost RAFOS trajectory reaches the Mid-Atlantic Ridge at $43^{\circ} \mathrm{S}, 16^{\circ} \mathrm{W}$. One of the ALACE floats also approached this location, which is the northern end of a deep passage of the Mid-Atlantic Ridge. A statistical analysis of the combined float data sets (Boebel et al., 1997a) indicates that at intermediate depth the northern part of the Antarctic Circumpolar Current and the South Atlantic Current converge towards this deep passage, probably by topographic steering. Thus a possible exchange between the SAC and ACC seems likely, and its dynamics are, as already noted by Davis et al. (1996), an urging unanswered key question of this region.

\subsection{Cross frontal mixing at the Confluence Zone}

The Confluence Zone is formed by the convergence of the southward Brazil Current and northward Falkland Current, which occurs on the South American shelf between $35^{\circ} \mathrm{S}$ and $40^{\circ} \mathrm{S}$ (Piola and Gordon, 1989). More formally, in the West of the South Atlantic, it can be defined as the narrow part of the Subantarctic Zone, which lies between the Subantarctic Front and the Brazil Current Front/Subtropical Front.

Olson (1988) noted a width of up to $300 \mathrm{~km}$ between the separation points of the Brazil and Falkland Currents from the western boundary. The exact location of the separation points and of the fronts proper is highly variable. Oscillations of some $5^{\circ}$ have been observed at sea surface for the point of separation in meridional direction. Some $200 \mathrm{~km}$ were found in the zonal direction for the actual positions of the fronts. The signal is primarily annual, but an interannual component also has been observed (Olson et al., 1988).

At greater depth the definition of Subantarctic Front can be approximated by the $4^{\circ} \mathrm{C}$ isotherm at $200 \mathrm{~m}$ depth (Peterson and Whitworth III, 1989). An indicator of the boundary of the Brazil Current Front is the $8^{\circ} \mathrm{C}$ isotherm at $500 \mathrm{~m}$ (Roden, 1986). Most likely, the frontal system is more stable in position at depth than near the sea surface due to the reduced influence of the seasonal atmospheric signal. Within the Confluence Zone it is believed that mixing occurs between newly ventilated, fresh AAIW that is advected along the outer edges of the retroflecting Falkland Current and the older AAIW that is advected southward within the western branch of the subtropical gyre underneath the Brazil Current (Maamaatuaiahutapu et al., 1993).

Within this experiment, three floats (float 150,155 and 159) enter the Confluence Zone. Due to the uncertainty in the geographical position of the SAF and STF, the location of the floats relative to fronts had to be derived from the floats pressure and temperature data, which will be discussed in the following along with the floats trajectories.

Float 159 (Fig. 12, green), launched at $39^{\circ} \mathrm{S}$, is captured 10 days after its launch by a cyclonic feature centered at about $40^{\circ} \mathrm{S} 50^{\circ} \mathrm{W}$. During the single revolution, lasting for about 30 days, it experiences significant shoaling (100 dbar) while flowing southwestward. During the southeastern segment of the cyclone it finds itself near $650 \mathrm{dbar}$ 

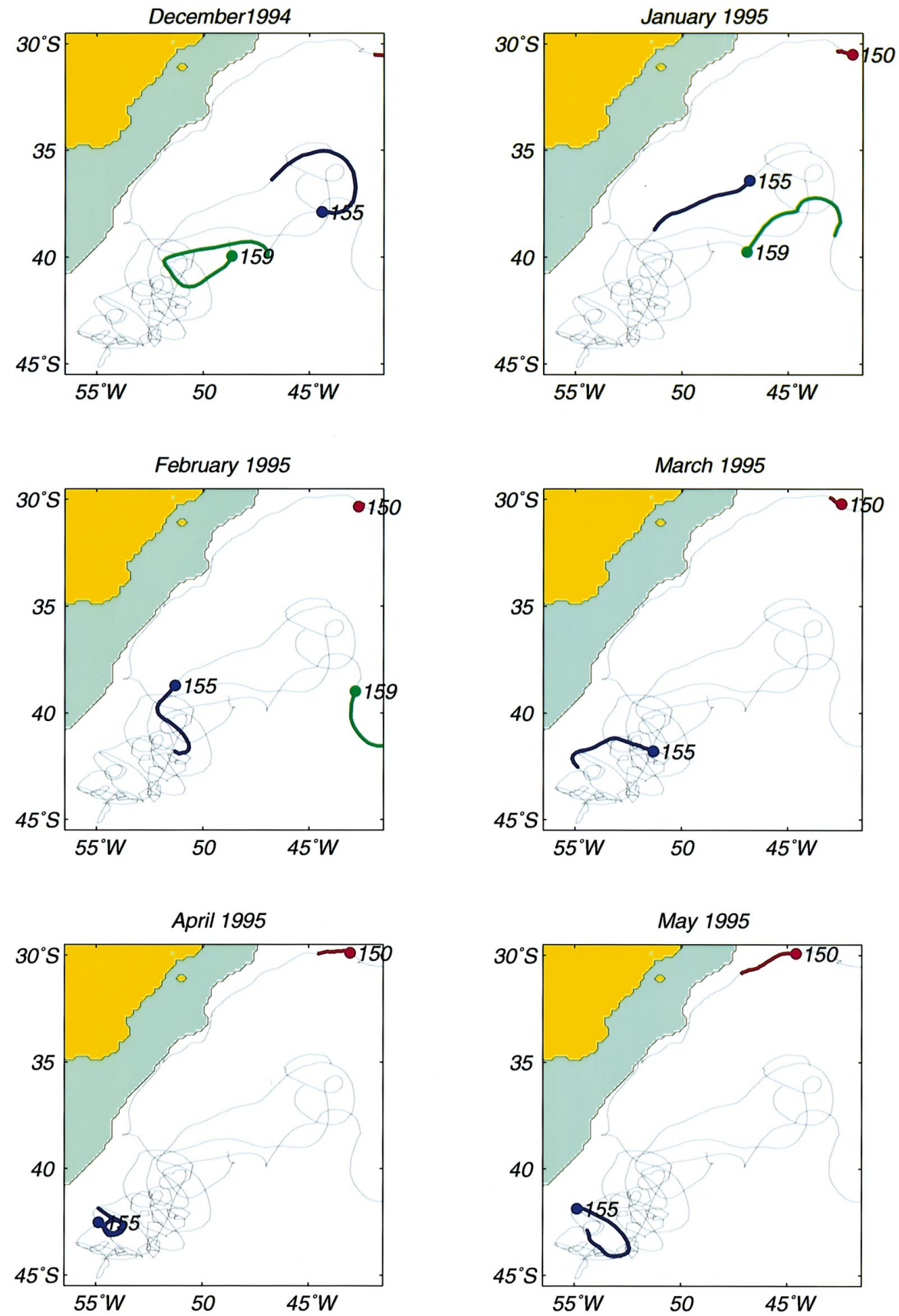

Fig. 12. Monthly segments (red, blue and green) of trajectories (gray) of floats 150, 155 and 159 between December 1994 and November 1995. Topography as in Fig. 1b. 

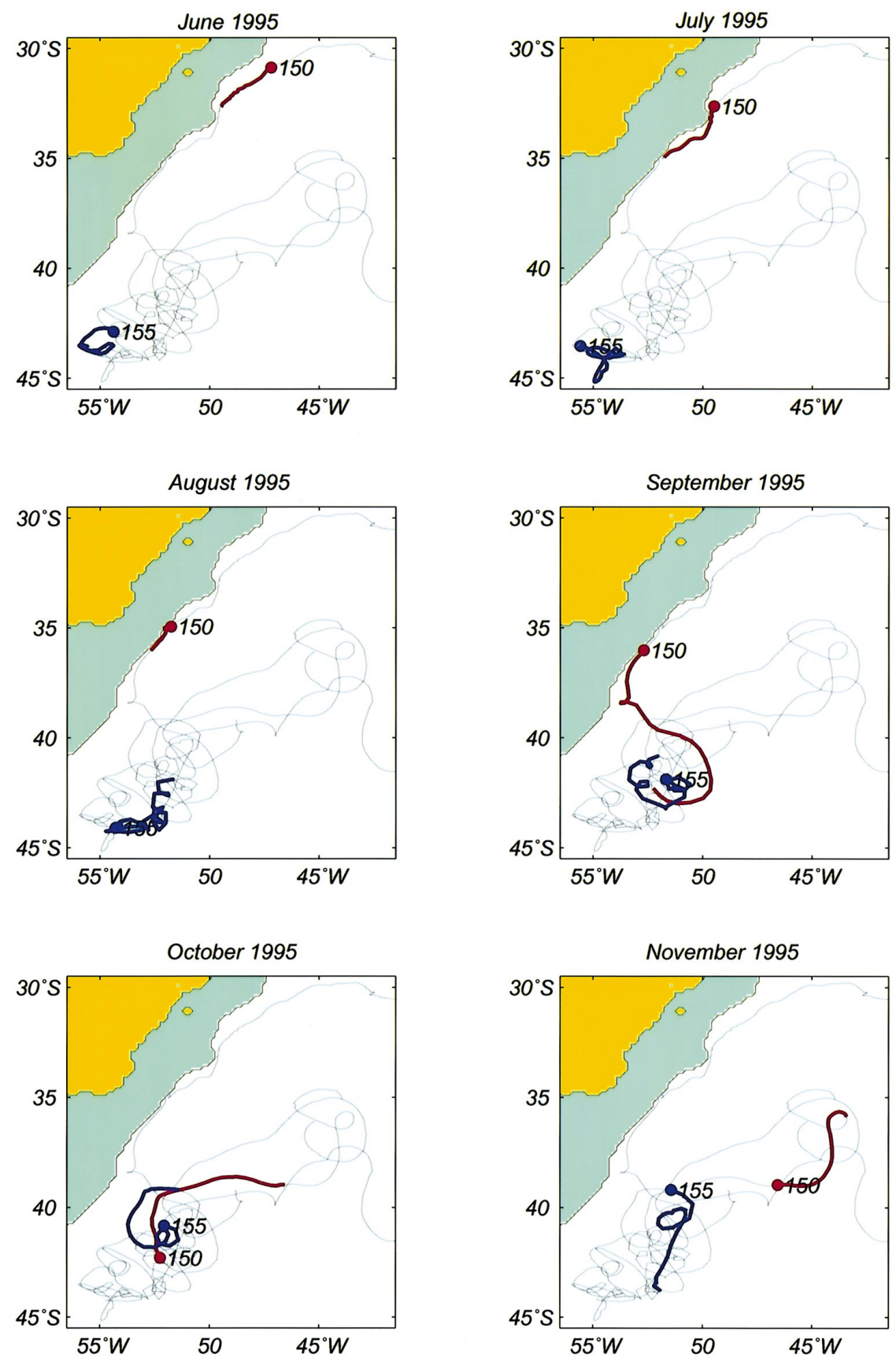

Fig. 12. Continued. 
and $3.7^{\circ} \mathrm{C}$, values that also hold true for the subsequent northeastward part of the trajectory. The cyclone has a radius of order $135 \pm 35 \mathrm{~km}$ (Table 5), and mean speeds at $31 \pm 15 \mathrm{~cm} \mathrm{~s}^{-1}$. Assuming a stratification of $5 \times 10^{-3}{ }^{\circ} \mathrm{Cdbar}^{-1}$, which is typical for the confluence region, the depth of the $4^{\circ} \mathrm{C}$ isotherm is at an estimated $590 \mathrm{dbar}$, well below the 200 dbar indicated for the SAF. Therefore this cyclonic feature is assumed to lie within the Confluence Zone. The subsequent trajectory indicates that water is expelled from the Confluence Zone, across the Subtropical Front and into the Subtropical Gyre.

Float 155 was launched in mid November 1994 at $36^{\circ} \mathrm{S}$, well north of the frontal system. It slowly drifts towards the Confluence Zone, taking a southeasterly coarse in mid-December 1995 (Fig. 12, blue). Some days into February 1995, it experiences a southeastward deflection, which leads to a cyclonic motion, drawing the float into the mixing area. Until end of July the float meanders in an apparently random pattern, not showing any coherent flow structure. In early August 1995, however, it is drawn into a cyclonic eddy that quickly translates north (Fig. 13). The cyclonic motion between 10 August and 7 October is analyzed in a similar way as described for floats 118 and 119. The separations of the rotational and translational components reveal 11 revolutions of 5.3 days average period. The float rotated at a tangential speed of $39 \mathrm{~cm} \mathrm{~s}^{-1}$ at $25 \mathrm{~km}$ radius, superposed to a translational speed of $20-25 \mathrm{~cm} \mathrm{~s}^{-1}$.

This smaller cyclonic eddy becomes part of the larger cyclonic motion at $40^{\circ} \mathrm{S}$, which is similar in size and position to the one observed by float 159 some 310 days earlier. In contrast to float 159 , however, float 150 is not expelled to the northeast, but continues to be trapped within the Confluence Zone and drifts back south in November 1995 (Fig. 12). Simultaneously with float 155, float 150 is captured by this cyclone and subsequently expelled into the subtropical gyre after it completed one revolution. Eddy parameters derived from this and the other float trajectories are calculated in a similar way as for the anticyclonic eddy at $11^{\circ} \mathrm{S}$ and are summarized in Table 5.

The trajectory of float 150 is at present the most compelling witness to the subtropical gyre recirculation. It was launched just east of the Rio Grande Rise at $31^{\circ} \mathrm{S}$ and slowly drifts across the Santos Plateau. In May 1995 it continues along the South American shelf break, just offshore the $1000 \mathrm{~m}$ isobath. In September 1995, the float is expelled from the western boundary at $38.5^{\circ} \mathrm{S}$. It accelerates to speeds of $60 \mathrm{~cm} \mathrm{~s}^{-1}$ and describes a small scale cyclonic motion. The south-eastward motion brings it near the position of the cyclonic vortex. Nearly simultaneously (lagging about 14 days behind) with float 155 , float 150 circles around this cyclone before being expelled to the northeast. During this time it shoals from about 950 to $850 \mathrm{dbar}$ while temperature is at $3.2^{\circ} \mathrm{C}$. From this, in analogy to the calculation above, a depth of 690 dbar can be estimated for the estimated $4^{\circ}$ isotherm, which puts the float north of the SAF.

Recently Peterson et al. (1996) have compared ALACE floats, $100 \mathrm{~m}$ drogued buoys and geostrophic velocity calculations within the Falkland current. A tongue of high velocity lies just to the east of the cyclonic vortex, which seems to act as bi-directional gateway into the region of high turbulence. The comparison of the position of the high 


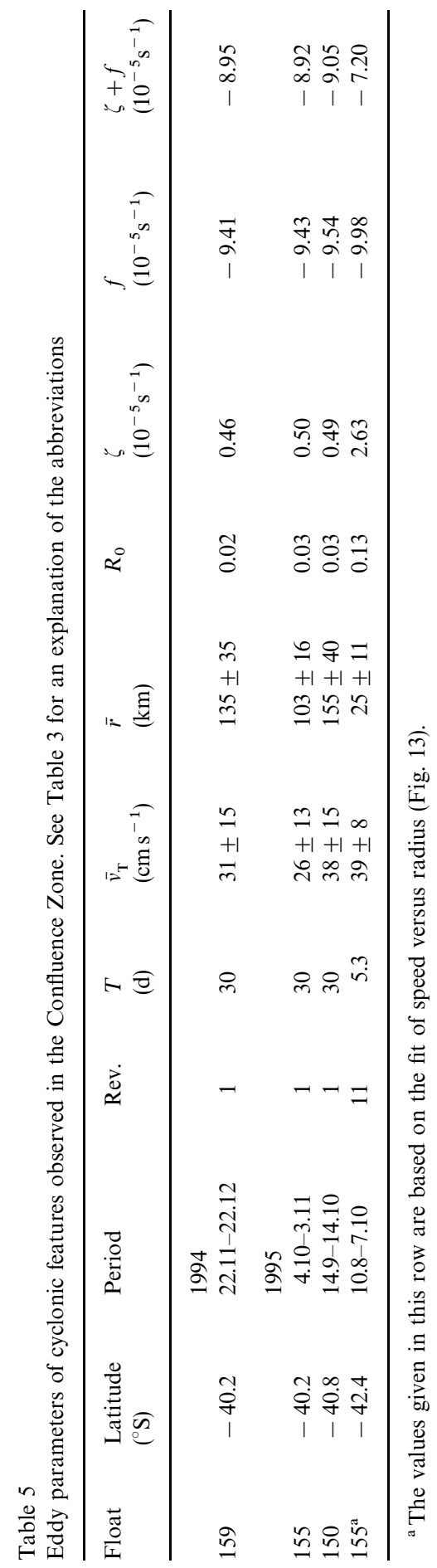



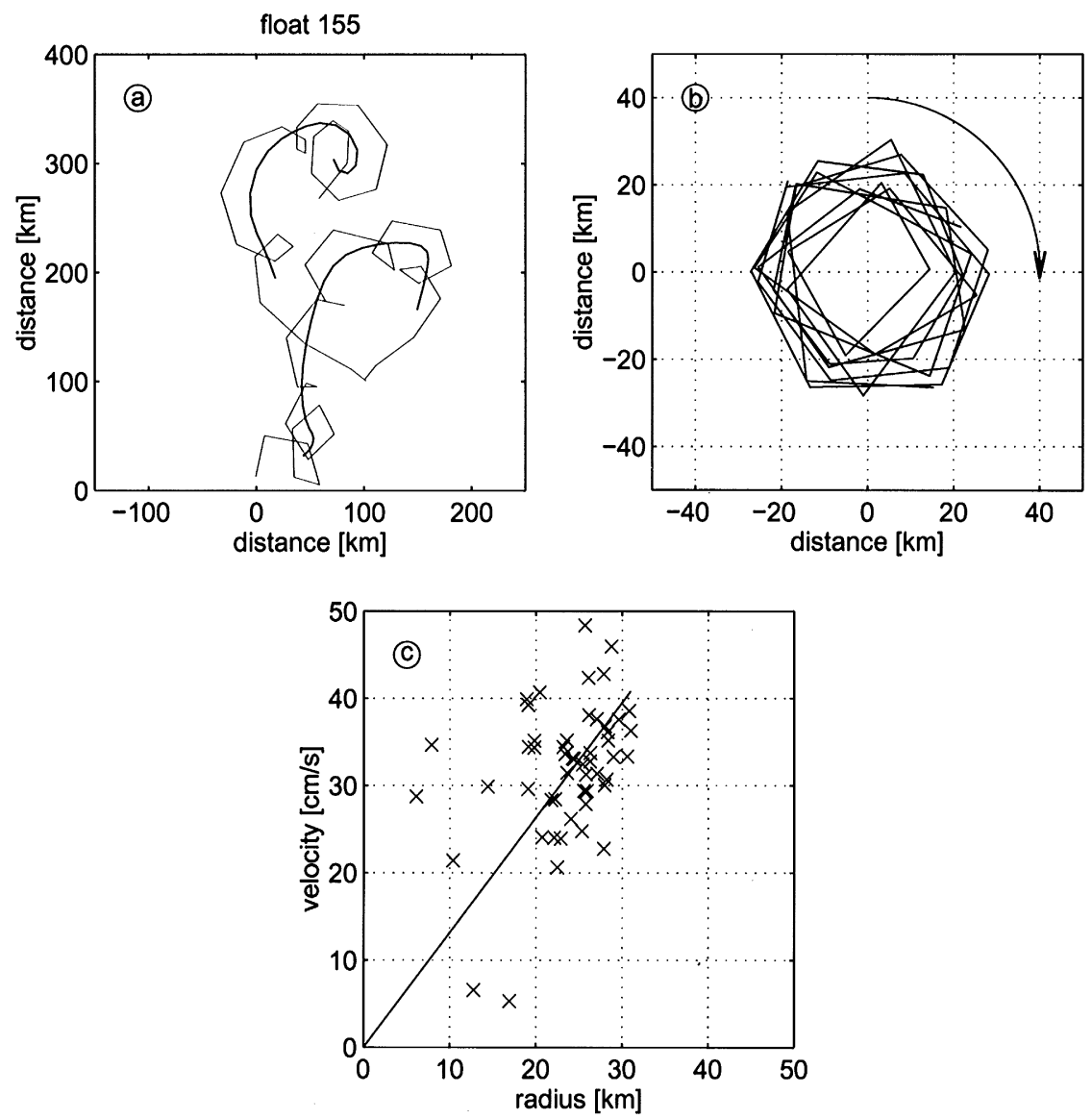

Fig. 13. (a) Raw (gray) and filtered (black) cyclonic part of trajectory float 155 with the exclusion of a short segment where the cyclonic motion was lost. (b) Trajectory of RAFOS float 155 relative to eddy center. (c) Scatter plot of velocity versus radius. The solid line represents a linear fit of the data, with a forced fix at the origin.

velocity core of the $100 \mathrm{~m}$ drogued drifters with the trajectories of the four ALACES that have translated along the outer edge of the Falkland retroflection and our floats shows strong agreement. The cyclonic motions described above all occur on the seaward site and adjacent to the retroflecting Falkland Current. The more random motion of float 155 , however, is situated directly underneath the high-velocity core described in Peterson et al. (1996).

Our current interpretation is that along the front, vigorous exchange of water masses occurs, driven by substantial mesoscale activity. Recirculated AAIW is drawn into the Confluence Zone, whereas fresher water is injected from the Subantarctic Front. This water, after thorough mixing in the Confluence Zone, is then expelled 
towards the calmer waters of the subtropical gyre by means of the cyclonic vortex observed at $40^{\circ} \mathrm{S}$. This scenario, we think, could be used as a working hypothesis for further studies, especially using isopycnal RAFOS floats to unravel the mechanisms at work within this melting pot of various flavors of Antarctic Intermediate Water.

\section{Conclusion}

The equatorial floats indicate that a broad eastward flow, embracing a predominantly westward EIC, provides a coherent description of the difficult equatorial regime at intermediate depth. Our and other data suggest that the direction of the Equatorial Intermediate Current follows an annual cycle. Floats at the western boundary exemplify a possibly frequent countercurrent to the northward IWBC. The migration of eddies provides a likely mechanism by which fresher subtropical and saltier tropical AAIW are mixed along the western boundary. The sluggish flow of AAIW in the western reaches of the tropical gyre suggests very little advective flow within this gyre system. No advective structure was resolved, at least at these easternmost longitudes of the gyre. The subtropical gyre return current is of remarkable zonal stability. A mean to eddy kinetic energy ratio near one is rarely observed in the ocean. In contrast the eastward SAC shows strong eddy kinetic energy due to large meanders. The position of the high velocity core of the SAC at intermediate depth coincides with the surface expression of the Subtropical Front. The confluence zone is marked by the inflow of aged, subtropical AAIW from the north and fresh AAIW from south and shallower layers. The Confluence Zone appears to be the melting pot of AAIW. Subsequently it is expelled from the Confluence Zone by means of a cyclonic vortex near $40^{\circ} \mathrm{S} 50^{\circ} \mathrm{W}$ into the subtropical gyre.

\section{Acknowledgements}

We would like to thank everybody involved in the Deep Basin Experiment for sharing the sound source array and technical knowledge. Especially B. Owens and P. Richardson (WHOI) as well as M. Menzel and M. Ollitrault (IFREMER) should be mentioned for their close cooperation in the deployment of sound sources, the discussion of timing information, and development of tracking software. K. Petuhov (nee Heidemann) relieved us of the tedious work of entering all the technical float data into a data base.

Crew and Officers of FS METEOR and FS POLARSTERN gave us a warm welcome during all cruises. Their expertise and patience have been an essential ingredient to this study. We also would like to thank the Alfred-Wegener-Institut for the continued support in form of ship time onboard FS POLARSTERN, which greatly contributed to the success of this project.

One of us (O.B.) would like to express his appreciation to the Alexander von Humboldt-Stiftung, currently enabling him to continue working at the University of Cape Town on this project and a closely related project around southern Africa. 
Last but not least, we would like to express our thankfulness to G. Siedler, who generated an environment in his department that allowed the float group to flourish and to experience some exciting and productive years during the WOCE period. Both the German WOCE in general and the IfM Kiel float group in particular have benefited from his expertise during the planning years and this float project specifically might not have started in the first place without his trust in the future of Lagrangian techniques. During the years that followed, a mutual sharing of human and monetary resources enabled us to overcome many technical difficulties, and finally, to enjoy success in a very exciting field of research.

\section{References}

Barnier, B., Marchesiello, P., de Miranda, A.P., 1996. Modelling the ocean circulation in the South Atlantic: a strategy for dealing with open boundaries. In: Wefer, G., Berger, W.H., Siedler, G., Webb, D.J. (Eds.), The South Atlantic: Present and Past Circulation. Springer, Berlin, pp. 289-304.

Boebel, O., Davis, R.E., Ollitrault, M., Peterson, R.G., Richardson, P.L., Schmid, C., Zenk, W., 1997a. First direct observations of the intermediate circulation of the western South Atlantic. Scienced (submitted).

Boebel, O., Schmid, C., 1995a. RAFOS floats in the Antarctic Intermediate Water of the South Atlantic. International WOCE Newsletter 18, 26-28.

Boebel, O., Schmid, C., 1995b. RAFOS Floats in the South Atlantic. Ber. Polarforschung 168, 6-11.

Boebel, O., Schmid, C., Zenk, W., 1997b. Flow and recirculation of Antarctic Intermediate Water across the Rio Grande Rise. Journal of Geophysical Research 102, 20 967-20 986.

Böning, C.W., 1988. Characteristics of particle dispersion in the North Atlantic: an alternative interpretation of SOFAR float results. Deep-Sea Research 35, 1379-1385.

Böning, C.W., Schott, F.A., 1993. Deep currents and eastward salinity tongue in the equatorial Atlantic: results from an eddy resolving primitive equation model. Journal of Geophysical Research 98, 6991-6999.

Bubnov, V.A., Vasilenko, V.M., Krivelerich, L.M., 1980. The study of low-frequency variability of currents in the tropical Atlantic. Deep-Sea Research (Suppl. II) 26, 199-216.

Buscaglia, J.L., 1971. On the circulation of the Intermediate Water in the southwestern Atlantic Ocean. Journal of Marine Research 29, 245-255.

Davis, R.E., Killworth, P.D., Blundell, J.R., 1996. Comparison of Autonomous Lagrangian Circulation Explorer and fine resolution Antarctic model results in the South Atlantic. Journal of Geophysical Research 101, 855-884.

Davis, R.E., Webb, D.C., Regier, L.A., Dufour, J., 1992. The Autonomous Lagrangian Circulation Explorer. Journal of Atmospheric and Oceanic Technology 9, 264-285.

Deacon, G.E.R., 1937. The hydrology of the Southern Ocean. Discovery Reports 15, 1-124.

England, M.H., Garcon, V.C., 1994. South Atlantic circulation in a World Ocean model. Annales Geophysicae 12, 812-825.

Figueroa, H.A., Olson, D.B., 1989. Lagrangian statistics in the South Atlantic as derived from SOS and FGGE drifters. Journal of Marine Research 47, 525-546.

Freeland, H.J., Rhines, P.B., Rossby, T., 1975. Statistical observations of the trajectories of neutrally buoyant floats in the North Atlantic. Journal of Marine Research, pp. 383-404.

Fu, L.L., 1996. The circulation and its variability of the South Atlantic Ocean: first results from the TOPEX/POSEIDON mission. In: Wefer, G., Berger, W.H., Siedler, G., Webb, D.J. (Eds.), The South Atlantic: Present and Past Circulation. Springer, Berlin, pp. 63-82.

Garzoli, S.L., Gordon, A.L., 1996. Origins and variability of the Benguela Current. Journal of Geophysical Research 101, 897-906.

Garzoli, S.L., Gordon, A.L., Kamenkovich, V., Pillsbury, S., Duncombe Rae, C., 1996. Variability and sources of the south eastern Atlantic circulation. Journal of Marine Research 54, 1039-1071. 
Larqué, L., Maamaatuaiahutapu, K., Garçon, V., 1997. On the intermediate and deep water flows in the South Atlantic Ocean. Journal of Geophysical Research 102, 12 425-12440.

Lutjeharms, J.R.E., 1996. The exchange of water between the South Indian and South Atlantic Oceans. In: Wefer, G., Berger, W.H., Siedler, G., Webb, D. (Eds.), The South Atlantic: Present and Past Circulation. Springer, Berlin, pp. 122-162.

Maamaatuaiahutapu, K., Garçon, V.C., Provost, C., Boulahdid, M., Bianchi, A.A., 1993. Spring and winter water mass composition in the Brazil-Malvinas Confluence. Journal of Marine Research, 97, 9493-9505.

Molinari, R.L., Voituriez, B., Duncan, P., 1981. Observations in the subthermocline undercurrent of the equatorial South Atlantic Ocean: 1978-1980. Oceanology Acta, pp. 451-456.

Müller, T.J., Ikeda, Y., Zangenberg, N., Nonato, L., 1996. Direct measurements of western boundary currents off Brazil between $19^{\circ} \mathrm{S}$ and $28^{\circ} \mathrm{S}$. Journal of Geophysical Research 103, 5429-5437.

Nof, D., 1983. The translation of isolated cold eddies on a sloping bottom. Deep-Sea Research 30, 171-182.

Ollitrault, M., Cortes, N., Loaëc, G., Rannou, J.-P., 1994a. MARVOR float present results from the SAMBA experiment. In: OCEANS 94 Proceedings III (OCEANS 94 OSATES Conf.), pp. 17-22.

Ollitrault, M., Loaëc, G., Dumortier, C., 1994b. MARVOR, a multicycle RAFOS float. Sea Technology 35, $39-44$.

Olson, D.B., Podesta, G.P., Evans, R.H., Brown, O.B., 1988. Temporal variations in the separation of the Brazil and Malvinas Currents. Deep-Sea Research, 1971-1990.

Peterson, R.G., Johnson, C.S., Krauss, W., Davis, R.E., 1996. Lagrangian measurements in the Malvinas Current. In: Wefer, G., Berger, W.H., Siedler, G., Webb, D. (Eds.), The South Atlantic: Present and Past irculation. Springer, Berlin, pp. 122-162.

Peterson, R.G., Whitworth III, T., 1989. The Subantarctic and Polar Fronts in relation to deep water masses through the southwestern Atlantic. Journal of Geophysical Research 94, 10 817-10838.

Piola, A.R., Gordon, A.L., 1989. Intermediate waters in the southwest South Atlantic. Deep-Sea Research $36,1-16$.

Ponte, R.M., Luyten, J., Richardson, P.L., 1990. Equatorial deep jets in the Atlantic Ocean. Deep-Sea Research 37, 711-713.

Reid, J.L., 1994. On the total geostrophic circulation of the North Atlantic Ocean: flow patterns, tracers and transports. Progress in Oceanography 33, 1-92.

Reid, J.L., Nowlin, W.D., Patzert, W.C., 1977. On the characteristics and circulation of the southwestern Atlantic Ocean. Journal of Physical Oceanography 7, 62-91.

Reid, J.R., 1996. On the circulation of the South Atlantic Ocean. In: Wefer, G., Berger, W.H., Siedler, G., Webb, D.J. (Eds.), The South Atlantic: Present and Past Circulation. Springer, Berlin, pp. 13-44.

Richardson, P.L., Schmitz Jr., W.J., 1993. Deep cross-equatorial flow in the Atlantic measured with SOFAR floats. Journal of Geophysical Research, 98, 8371-8388.

Roden, G.I., 1986. Thermohaline Fronts and baroclinic flow in the Argentine Basin during the Austral Spring 1984. Journal of Geophysical Research, 5075-5093.

Rossby, T., Dorson, D., Fontaine, J., 1986. The RAFOS System. Journal of Atmospheric and Oceanic Technology 3, 672-679.

Schmid, C., Schäfer, H., Podestá, G., Zenk, W., 1995. The Vitória Eddy and its relation to the Brazil Current. Journal of Physical Oceanography 25, 2532-2546.

Schott, F.A., Fischer, J., Stramma, L., 1998. Transports and pathways of the upper-layer circulation in the western tropical Atlantic. Journal of Physical Oceanography 28, 1904-1928.

Schott, F.A., Stramma, L., Fischer, J., 1995. The warm water inflow into the western tropical Atlantic boundary regime, spring 1994. Journal of Geophysical Research 100, 24 745-24760.

Siedler, G., Balzer, W., Müller, T.J., Onken, R., Rhein, M., Zenk, W., 1993. WOCE South Atlantic 1992, Cruise No. 22, 22 September 1992-31 January 1993. METEOR Berichte 93-5, Universität Hamburg, Hamburg, pp. 131.

Speer, K.G., Holfort, J., Reynaud, T., Siedler, G., 1996. South Atlantic heat transport. In: Wefer, G., Berger, W.H., Siedler, G., Webb, D.J. (Eds.), The South Atlantic: Present and Past Circulation. Springer, Berlin, pp. $105-120$. 
Stalcup, M.C., Metcalf, W.G., 1966. Direct measurements of the Atlantic Equatorial Undercurrent. Journal of Marine Research 24, 44-55.

Stramma, L., Fischer, J., Reppin, J., 1995. The North Brazil Undercurrent. Deep-Sea Research 42, 773-795.

Stramma, L., Peterson, R., 1990. The South Atlantic Current. Journal of Physical Oceanography 20, $846-859$.

Suga, T., Talley, L.D., 1995. Antarctic Intermediate Water circulation in the tropical and subtropical South Atlantic. Journal of Geophysical Research 100, 13441-13 453.

Taft, B.A., 1963. Distribution of salinity and dissolved oxygen on surfaces of uniform potential specific volume in the South Atlantic, South Pacific, and Indian Oceans. Journal of Marine Research 21, $129-146$.

Talley, L.D., 1996. Antarctic Intermediate Water in the South Atlantic. In: Wefer, G., Berger, W.H., Siedler, G., Webb, D. (Eds.), The South Atlantic: Present and Past Circulation. Springer, Berlin, pp. 219-238.

Taylor, G.I., 1921. Diffusion by continuous movements. Proceeding of the London Mathematical Society 20.

Tsuchiya, M., Talley, L.D., McCartney, M.S., 1994. Water-mass distribution in the western South Atlantic; a section from South Georgia Island (54S) northward across the equator. Journal of Marine Research $52,55-81$.

WCRP, 1988. WOCE Implementation plan, World Climate Research Programme II, WMO/ITD No. 242, pp. 74.

Weisberg, R.H., 1980. Equatorial waves during GATE and their relation to the mean zonal circulation. Deep-Sea Research (Suppl. II) 236, 179-198.

Weisberg, R.H., Miller, L., Horigan, A., Knauss, J.A., 1980. Velocity observations in the equatorial thermoclinic during GATE. Deep-Sea Research (Suppl. II) 26, 217-248.

Zangenberg, N., Siedler, G., 1997. The path of the North Atlantic Deep Water in the Brazil Basin. Journal of Geophysical Research 103, 5419-5428.

Zenk, W., Müller, T.J., 1995. WOCE studies in the South Atlantic, Cruise No. 28, 29 March-14 June 1994. METEOR-Berichte 95-1, Universität Hamburg, Hamburg.

Zenk, W., Schmid, C., Boebel, O., 1998. WOCE floats in the South Atlantic. International WOCE Newsletter 30, 39-42. 